\title{
Selenium-rich dissolved organic matter determines selenium uptake in wheat grown on Low-selenium arable land soils
}

\author{
Supriatin Supriatin • Liping Weng • Rob N. J. Comans
}

Received: 4 February 2016 / Accepted: 19 April 2016/Published online: 5 May 2016

(C) The Author(s) 2016. This article is published with open access at Springerlink.com

\begin{abstract}
Aims The study aimed to find soil parameters that are best related to Se plant uptake for low Se soils with predominantly organic Se, and to explore the mechanisms that control Se bioavailability in the soils under study.

Methods A pot experiment using nineteen soil samples taken from different fields of arable land (potato fields) in the Netherlands was conducted on summer wheat (Triticum aestivum L.). Selenium in wheat shoots and soil parameters, including basic soil properties, C:N ratio, inorganic selenite content, and $\mathrm{Se}$ and organic $\mathrm{C}$ in different soil extractions $\left(0.01 \mathrm{M} \mathrm{CaCl}_{2}, 0.43 \mathrm{M}\right.$ $\mathrm{HNO}_{3}$, hot water, ammonium oxalate, aqua regia) were analysed. Regression analysis was performed to identify soil parameters that determine Se content in wheat shoots.

Results The regression model shows that Se:DOC ratio in $0.01 \mathrm{M} \mathrm{CaCl}_{2}$ soil extraction explained about $88 \%$ of the variability of Se uptake in wheat shoots. Selenium uptake increased with $\mathrm{Se}$ :DOC ratio in $\mathrm{CaCl}_{2}$ extraction, which can be interpreted as a measure of the content of soluble Se-rich organic molecules. Selenium:DOC ratio in $\mathrm{CaCl}_{2}$ extraction and Se uptake increased towards higher soil $\mathrm{pH}$ and lower soil $\mathrm{C}: \mathrm{N}$ ratio. The soil $\mathrm{C}: \mathrm{N}$ ratio is also negatively correlated to Se:organic $\mathrm{C}$ ratio in
\end{abstract}

Responsible Editor: Philip John White.

S. Supriatin $\cdot$ L. Weng $(\bowtie) \cdot$ R. N. J. Comans

Department of Soil Quality, Wageningen University, PO Box 47, 6700 AA Wageningen, The Netherlands

e-mail: liping.weng@wur.nl other extractions $\left(0.43 \mathrm{M} \mathrm{HNO}_{3}\right.$, hot water, ammonium oxalate, aqua regia), indicating that at low soil $\mathrm{C}: \mathrm{N}$ ratio soil organic matter is richer in Se. Contrarily, the soil $\mathrm{pH}$ is positively and strongly correlated to Se:organic C ratio in $\mathrm{CaCl}_{2}$ and hot water extractions, but only weakly correlated to Se:organic $\mathrm{C}$ ratio in other extractions. Conclusions Selenium-rich dissolved organic matter is the source of bioavailable Se in low Se soils with predominantly organic Se. The soil $\mathrm{pH}$ and quality of soil organic matter (i.e. soil C:N ratio) are the main soil properties determining Se bioavailability in these soil types.

Keywords Selenium $\cdot$ Plant uptake $\cdot$ Dissolved organic $\mathrm{C} \cdot$ Calcium chloride extraction $\cdot$ Soil $\mathrm{pH} \cdot$ Soil C:N ratio

$\begin{array}{ll}\text { Abbreviations } \\ \text { CHN } & \text { Carbon, Hydrogen, Nitrogen } \\ \text { C:N } & \text { Carbon:Nitrogen } \\ \text { DOC } & \text { Dissolved Organic Carbon } \\ \text { DOM } & \text { Dissolved Organic Matter } \\ \text { DON } & \text { Dissolved Organic Nitrogen } \\ \text { FA } & \text { Fulvic Acids } \\ \text { GR } & \text { Grass } \\ \text { HPLC } & \text { High Performance Liquid } \\ & \text { Chromatography } \\ \text { Hy } & \text { Hydrophilic Acids } \\ \text { ICP-AES } & \text { Inductively Coupled Plasma- } \\ & \text { Atomic Emission Spectroscopy } \\ \text { ICP-MS } & \text { Inductively Coupled Plasma- } \\ & \text { Mass Spectroscopy } \\ \text { IPE } & \text { International Plant-analytical } \\ & \text { Exchange }\end{array}$




$\begin{array}{ll}\text { NIR } & \begin{array}{l}\text { Near infrared } \\ \text { National Institute of Standard } \\ \text { and Technology }\end{array} \\ \text { NPK } & \begin{array}{l}\text { Nitrogen, Phosphorus, Potassium } \\ \text { Se }\end{array} \\ \text { Selenium } \\ \text { SFA } & \text { Segmented Flow Analyser } \\ \text { UV } & \text { Ultraviolet }\end{array}$

\section{Introduction}

Selenium (Se) is an essential micronutrient for cattle and humans, which plays a role in the production of antioxidant in cell systems. Generally, Se enters cattle and humans through grasses or crops in the food chain. An adequate level of Se in grasses and crops is determined by the level of available Se in soil. In agricultural soils with low Se availability, Se fertilizer can be applied to increase the Se content in plants. Understanding soil parameters and mechanisms affecting Se uptake by plants may help us to accurately predict the Se status in soils, design sustainable soil management and Se fertilization recommendations, avoid problems of Se deficiency, toxicity and environmental pollution.

In soil, Se can be present as inorganic and organic species. There are several oxidation states of inorganic $\mathrm{Se}$, ranging from +6 (selenate), +4 (selenite), 0 (elemental Se), to -2 (selenides) (Hartikainen 2005). The inorganic selenate $\left(\mathrm{SeO}_{4}{ }^{2-}\right)$ and selenite $\left(\mathrm{SeO}_{3}{ }^{2-}\right)$ can be found as soluble forms or as adsorbed (mainly selenite) to soil mineral surfaces, such as clay and metal (hydr)oxides, whereas elemental $\mathrm{Se}\left(\mathrm{Se}^{0}\right)$ and selenides $\left(\mathrm{Se}^{2-}\right)$ are present as insoluble forms (Hartikainen 2005). The chemical nature of organic Se in soils is not very well known. Previous studies have reported different forms of organic Se present in soil, such as selenomethionine $\left(\mathrm{C}_{5} \mathrm{H}_{11} \mathrm{NO}_{2} \mathrm{Se}\right)$, methane seleninic acids $\left(\mathrm{CH}_{3} \mathrm{SeOOH}\right)$ and trimethyl selenium ion $\left(\left(\mathrm{CH}_{3}\right)_{3} \mathrm{Se}^{+}\right)$(Abrams and Burau 1989; Abrams et al. 1990a; Stroud et al. 2012; Tolu et al. 2014; Yamada and Hattori 1989). It has also been suggested that organic Se in soil is present as seleno-amino acid incorporated into protein or peptides in humic and fulvic acid fractions of soil organic matter (Kang et al. 1991). Spectroscopic evidence shows that organic Se in soils is present in a structure of $\mathrm{C}-\mathrm{Se}-\mathrm{C}$, similar to that in methylselenocysteine and selenomethionine (Mehdawi et al.
2015). Our previous studies showed that Se in low Se Dutch agricultural soils is predominantly in organic form both in soil solution and solid phase, and only a small fraction (on average $5 \%$ ) is present as inorganic Se (mainly selenite) (Supriatin et al. 2015a, b).

Mechanisms and soil parameters controlling Se availability and plant uptake are still not well understood. Among different Se forms present in soil, soluble $\mathrm{Se}$ is the main source available for plant uptake. However, in the soil solution, Se can be present as both inorganic selenate, selenite and as organic Se (Weng et al. 2011). Probably not all soluble Se species can be taken up by plants directly. Inorganic selenate can be taken up directly by roots and easily translocated to the shoots, whereas selenite tends to be accumulated in root tissue (Hopper and Parker 1999; Kikkert and Berkelaar 2013; Li et al. 2008; Zayed et al. 1998). Previous studies have shown that some small organic Se molecules, such as selenomethionine and selenocystine, can also be taken up by plants (Abrams et al. 1990b; Kikkert and Berkelaar 2013; Williams and Mayland 1992), and selenomethionine is more readily taken up by roots and quickly transported to the shoots than selenocystine (Kikkert and Berkelaar 2013). However, Supriatin et al. (2015a) showed that most of soluble Se in Dutch agricultural soils consists of colloidal-sized organic Se, whereas inorganic selenite or selenate and small organic Se molecules were hardly measurable. The colloidalsized organic Se, due to its relatively large molecular size, is probably not directly available for plants. In addition to the concentration of soluble, directly available Se species, the release rate of Se into soil solution from different forms of Se in soil solid phase determines the buffer capacity of soil in case of fast uptake.

Both pot and field experiments have been performed to derive soil parameters that control Se uptake by plants. Most of these pot experiments were aimed to understand the soil parameters influencing the efficiency of Se uptake from Se fertilizers added (EichGreatorex et al. 2007; Gissel-Nielsen 1971; HurdKarrer 1938; Johnsson 1991). It was found that soil organic matter content, $\mathrm{pH}$, clay content and sulphate concentration influence Se plant uptake under inorganic Se fertilization treatments (Eich-Greatorex et al. 2007; Gissel-Nielsen 1971; Hurd-Karrer 1938; Johnsson 1991). Studies on the relationship between soil parameters and Se plant uptake without Se fertilization were conducted mainly in field experiments, in which organic matter content, $\mathrm{pH}$, total Se content, potassium 
dihydrogen phosphate extractable S, and water, potassium dihydrogen phosphate or ammonium acetate-EDTA extractable Se were found of relevance (De Temmerman et al. 2014; Stroud et al. 2010; Wang and Sippola 1990; Zhao et al. 2005). In general, the above mentioned soil parameters were weakly correlated with Se uptake in crops, explaining $48 \%$ of the variation at maximum (De Temmerman et al. 2014; Wang and Sippola 1990). However, Stroud et al. (2010) showed that the variability of Se uptake by wheat grains can be predicted accurately $\left(\mathrm{R}^{2}=0.86, p<0.001\right)$ by taking into account both total Se and potassium dihydrogen phosphate extractable Se and S in soil. Their experiment was performed in soils with low levels of total Se (i.e. 245 to $590 \mu \mathrm{g} \mathrm{kg}^{-1}$ ) and up to $50 \%$ of extractable soil Se is inorganic selenite. Similarly, Zhao et al. (2005) showed that potassium dihydrogen phosphate extractable Se was strongly correlated with Se uptake of tea plant $\left(\mathrm{R}^{2}=0.95, p<0.01\right)$ grown on selenium rich soils. Up to now, there is no comprehensive research determining the important soil factors controlling Se uptake in crops grown on non-fertilized soils under controlled conditions, especially in low Se soils with predominantly organic Se, such as in Dutch agricultural soils, and there is a lack of understanding of the underlying controlling factors and mechanisms.

The objectives of this study are (1) to find soil parameters that are best related to plant uptake of Se under controlled conditions for Dutch agricultural soils with a relatively low Se content and predominantly organic Se, and (2) to explore the mechanisms that control the bioavailability of Se in the soils under study.

\section{Materials and methods}

\section{Soil samples}

Nineteen soil samples were taken from arable fields (potato fields, top soil 0 to $20 \mathrm{~cm}$ ) in the Netherlands in May 2013. The soil samples consist of four soil types, i.e. sand, clay, loess, and reclaimed peat soils (Table 1). Most of them $(n=16)$ have been used in the previous study on the effects of drying on soluble $\mathrm{Se}$ and $\mathrm{Cu}$ concentrations in soils (Supriatin et al. 2015a). Before sampling, mineral nitrogen $(\mathrm{N})$, phosphorus $(\mathrm{P})$, and potassium $(\mathrm{K})$ fertilizers have been applied in the fields for the coming season following the scheme of individual farmers. No Se fertilizer was applied to the soils.

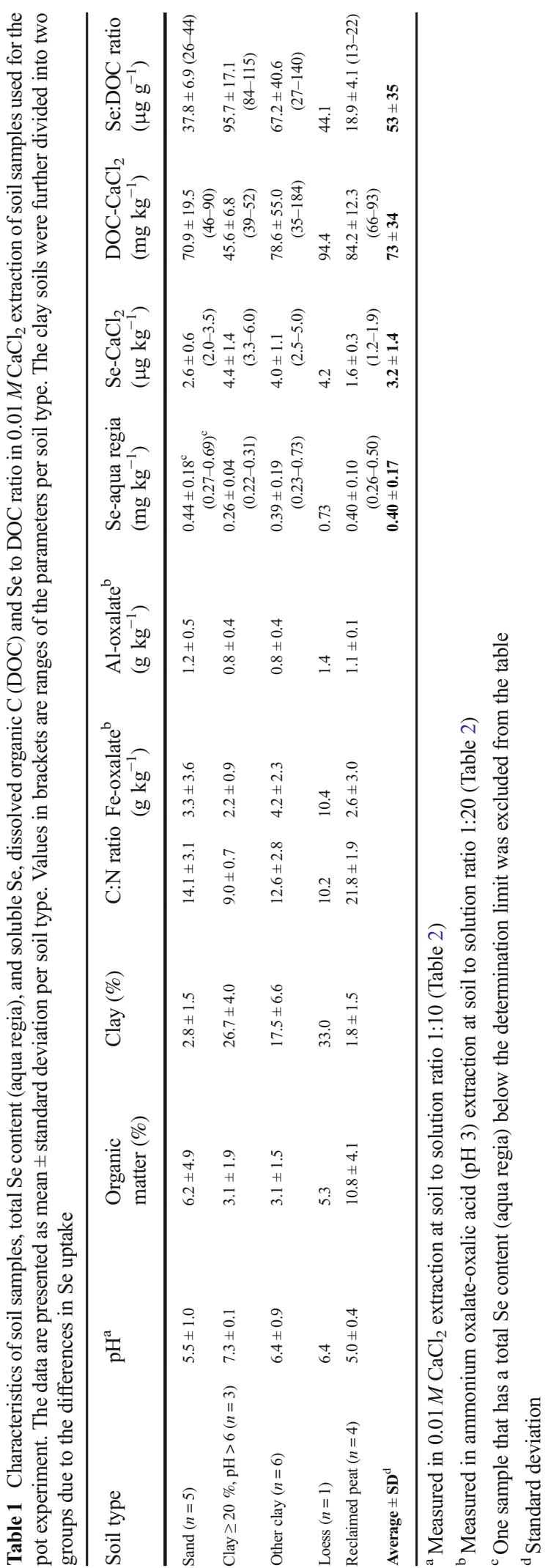


After sampling, the soils were oven dried at $20^{\circ} \mathrm{C}$ under forced air ventilation for $48 \mathrm{~h}$. Afterwards, the roots and gravels were removed from the soils and the soil samples were ground, passed through a $2 \mathrm{~mm}$ sieve, and stored at room temperature $\left(20 \pm 1{ }^{\circ} \mathrm{C}\right)$ for further use in the pot experiment. Sub soil samples were oven-dried at $40{ }^{\circ} \mathrm{C}$ under forced air ventilation for 24 to $48 \mathrm{~h}$, ground, and passed through a $2 \mathrm{~mm}$ sieve for further soil analysis.

\section{Pot experiment}

A pot experiment under controlled greenhouse conditions was designed to derive relations between soil parameters and Se content in shoots of summer wheat (Triticum aestivum L.). The pot experiment was conducted between June and August, 2013. Each pot was filled with $1.5 \mathrm{~kg}$ of dried soil, in duplicates for each soil sample. Before filling the pots, each soil was adjusted to $60 \%$ of its field water holding capacity by adding deionized water. The moistened soils in the pots were allowed to equilibrate for 1 week at room temperature $\left(20 \pm 1^{\circ} \mathrm{C}\right)$ before sowing. The pots were covered with a plastic sheet during the equilibration time to prevent evaporation. Afterwards, the pots were moved to the greenhouse. Six seeds of summer wheat were sown in each pot. The pots were covered with a plastic sheet for one more week until the seeds were germinated. After that, the plastic sheet was removed and the plants were thinned to three or four plants per pot. The water contents of the soils were maintained at $60 \%$ of field water holding capacity during the growth of the plants by daily watering. The experiments were conducted in the greenhouse with a photoperiod of $16 \mathrm{~h}(06: 00$ to 21:00 h), light intensity of $400 \mathrm{~W} \mathrm{~m}^{-2}$ (16 SON-T agro lamps), day/night temperature of $21 / 19^{\circ} \mathrm{C}$, and relative humidity of $60 \%$. The location of the pots on the greenhouse table was reshuffled randomly every 3 days. The weeds, pests and insects were suppressed during the growth of the plants.

\section{Plant samples}

The plants were harvested 53 days after sowing. At this stage, the spikes and flowers have already emerged. The green shoots were harvested, which include the second to fifth leaves, stems, spikes, and green tillers. The yellow shoots including the first leaf and yellow coloured tillers were also harvested and separated from the green shoots. Afterwards, the green and yellow shoots were washed with deionized water to remove soil particles and oven dried at $70{ }^{\circ} \mathrm{C}$ for $72 \mathrm{~h}$. The total dry matter of shoots per pot was weighted (dry weight of green plus yellow shoots). Only the dried green shoots were milled for further Se analysis.

\section{Plant digestion}

Selenium content in plant samples was determined after digestion with concentrated $\mathrm{HNO}_{3}$ and $\mathrm{H}_{2} \mathrm{O}_{2}$ in a microwave with a closed system. A preliminary test on this method was performed using standard reference sample 1573a (tomato leaves) obtained from NIST and IPE 100 (grass, Poaceae, GR 94) obtained from Wepal, the Netherlands, three grass samples in which one was spiked with selenite, two maize shoot samples, and two potato tuber samples. Recovery of Se was $98 \pm 2$ and $96 \pm 4 \%$ in the standard reference sample $1573 \mathrm{a}$ and IPE 100, respectively and $92 \pm 2 \%$ in the spiked grass sample. The variations among three replicates of Se content in the two grass samples, two maize shoot samples, and two potato tuber samples were on average 5, 2 and $6 \%$, respectively.

In the digestion, $0.4 \mathrm{~g}$ of plant sample was put into a Teflon destruction vessel and $5 \mathrm{~mL}$ of concentrated $\mathrm{HNO}_{3}$ was added to the sample and mixed. Afterwards, the destruction vessel was closed and allowed to stand overnight at room temperature (20 $\pm 1{ }^{\circ} \mathrm{C}$ ). After that, the vessel was put into a microwave to allow the first digestion step to take place. After the first digestion step was completed, the sample was taken out and cooled down. About $1 \mathrm{~mL}$ of $\mathrm{H}_{2} \mathrm{O}_{2}$ was added to the sample and the second digestion step in the microwave took place. At the end, the sample was transferred into a $50 \mathrm{~mL}$ grainer tube and the vessel was washed twice with ultrapure water. The volume of the sample was made up to $50 \mathrm{~mL}$ by adding ultrapure water. Selenium concentration in the sample was measured.

\section{Soil extractions}

A series of single-step extractions was performed on the soil samples, including $0.01 \mathrm{M} \mathrm{CaCl}_{2}, 0.43 \mathrm{MHNO}_{3}$, hot water, and ammonium oxalate extractions and aqua regia digestion. An overview of the extraction methods is presented in Table 2, and more details can be found in Supriatin et al. (2015b). Selenium, dissolved organic C (DOC), $\mathrm{pH}$, major anions (i.e. $\mathrm{S}=$ total extracted sulphur, $\mathrm{P}=$ total extracted phosphorus, $\mathrm{P}-\mathrm{PO}_{4}=$ total extracted 
Table 2 An overview of soil extractions performed on the soil samples used in this study

\begin{tabular}{|c|c|c|c|c|c|c|c|}
\hline Extraction & $\begin{array}{l}\text { Possible pool } \\
\text { representing }\end{array}$ & $\begin{array}{l}\text { Method adopted } \\
\text { from }\end{array}$ & $\mathrm{SSR}^{\mathrm{b}}$ & $\begin{array}{l}\text { Extraction/ } \\
\text { digestion }(\mathrm{h})\end{array}$ & $\begin{array}{l}\text { Centrifugation } \\
\text { (rpm and min) }\end{array}$ & Filter & Parameter measured \\
\hline $0.01 \mathrm{MCaCl}_{2}$ & Soluble (Houba et al. 2000) & Houba et al. (2000) & $1: 10$ & 2 & $3000 ; 10$ & $0.45 \mu \mathrm{m}^{\mathrm{d}}$ & $\begin{array}{l}\mathrm{Se}, \mathrm{DOC}, \mathrm{pH}, \mathrm{S}, \mathrm{P}, \\
\mathrm{PO}_{4}, \mathrm{NH}_{4}, \mathrm{NO}_{3}+ \\
\mathrm{NO}_{2} \text {, total soluble } \mathrm{N}\end{array}$ \\
\hline $0.43 \mathrm{MHNO}_{3}{ }^{\mathrm{a}}$ & Reactively adsorbed & - & $1: 10$ & 4 & $3000 ; 10$ & Paper $^{\mathrm{e}}$ & $\mathrm{Se}, \mathrm{DOC}$ \\
\hline Hot water & $\begin{array}{l}\text { Labile organic matter } \\
\text { associated } \\
\text { (Ghani et al. 2003) }\end{array}$ & Ghani et al. (2003) & $1: 10$ & $16\left(80^{\circ} \mathrm{C}\right)$ & $3500 ; 20$ & $0.45 \mu \mathrm{m}^{\mathrm{d}}$ & $\mathrm{Se}, \mathrm{DOC}, \mathrm{pH}, \mathrm{S}, \mathrm{P}, \mathrm{PO}_{4}$ \\
\hline $\begin{array}{l}\text { Ammonium oxalate - } \\
\quad \text { oxalic acid }(\mathrm{pH} \mathrm{3})^{\mathrm{c}}\end{array}$ & $\begin{array}{l}\text { Adsorbed to amorphous } \\
\text { Fe and Al oxides } \\
\text { (Keskinen et al. 2009) }\end{array}$ & $\begin{array}{l}\text { McKeague and } \\
\text { Day (1966) }\end{array}$ & $1: 20$ & 2 (in the dark) & $3000 ; 10$ & No & $\mathrm{Se}, \mathrm{UV}, \mathrm{S}, \mathrm{P}, \mathrm{Fe}, \mathrm{Al}$ \\
\hline Aqua regia digestion & $\begin{array}{l}\text { (Pseudo) total content } \\
\text { (Keskinen et al. 2009) }\end{array}$ & - & $1: 100$ & $\begin{array}{l}\text { Overnight, plus } 2 \mathrm{~h} \\
\text { in a microwave } \\
\text { at } 170{ }^{\circ} \mathrm{C}\end{array}$ & No & Paper $^{\mathrm{e}}$ & $\mathrm{Se}$ \\
\hline
\end{tabular}

\footnotetext{
${ }^{\text {a }}$ Especially for soil samples that have $\mathrm{pH} \geq 7$, about $0.2 \mathrm{~mL}$ of $5 \mathrm{MHNO}_{3}$ was added to neutralise the carbonates in the soil samples

b Soil to solution ratio

c The soil extracts were further fractionated on HPLC - ICP-MS

d Syringe filter (Whatman Aqua 30/0.45 CA)

${ }^{\text {e } A s h-f r e e ~ p a p e r ~ f i l t e r ~(W h a t m a n ~ 589 / 3 ~ n r . ~ 10300212) ~}$
}

ortho-phosphate), soluble inorganic $\mathrm{N}\left(\mathrm{N}-\mathrm{NH}_{4}, \mathrm{~N}^{-\mathrm{NO}_{3}}+\right.$ $\mathrm{N}-\mathrm{NO}_{2}$ ) and total soluble $\mathrm{N}$ were measured in the corresponding soil extractions as presented in Table 2. Concentration of dissolved organic N (DON) in $0.01 \mathrm{M}$ $\mathrm{CaCl}_{2}$ extraction was derived from the difference between total soluble $\mathrm{N}$ and soluble inorganic $\mathrm{N}$. Concentrations of $\mathrm{Fe}$ and $\mathrm{Al}$ in the ammonium oxalate extraction were measured as well, which represent the amount of amorphous (hydr)oxides of the corresponding metals (Tables 1 and 2). Concentration of DOC in ammonium oxalate extraction was derived indirectly from UV-absorbance measured at $254 \mathrm{~nm}$ wavelength after diluting the extracts 50 times and correcting for $\mathrm{Fe}$ concentration in the extracts as described in detail in Supriatin et al. (2015b).

Inorganic selenite in ammonium oxalate extraction measured using HPLC - ICP-MS

\section{A High Performance Liquid Chromatography (HPLC)} system with an anion exchange column coupled online with High Resolution ICP-MS was used to measure inorganic selenite, selenate and organic Se in the ammonium oxalate extraction of the soil samples. The details of the solutions and procedure used in the HPLC analysis were described elsewhere (Supriatin et al. 2015b). The soil samples were extracted using ammonium oxalate - oxalic acid $(\mathrm{pH} 3)$ solution (Table 2). Initial total $\mathrm{Se}$ concentrations in the soil extracts were measured before the HPLC analysis. Concentrations of selenite and selenate in the soil extracts were determined from the peak areas of the chromatograms. Concentrations of organic Se were calculated from the difference between total Se concentrations and inorganic Se (selenite plus selenate) concentrations in the corresponding soil extracts. There was no interference for Se in the soil extracts was observed during the ICP-MS analysis because we used a High Resolution ICP-MS in high resolution mode to measure isotope ${ }^{78} \mathrm{Se}$ for $\mathrm{Se}$ measurement in the samples (Table 3). This high resolution mode of ICP-MS can separate isotope ${ }^{78} \mathrm{Se}$ from all the possible interferences, except that for $\mathrm{Kr}$ that cannot be separated from ${ }^{78} \mathrm{Se}$, however, we solve that by measuring ${ }^{83} \mathrm{Kr}$ and compensate the ${ }^{78} \mathrm{Se}$ signal for that (Personal communication). Similar ICP-MS conditions were also applied for Se analysis in other matrices of soil extractions (Table 2).

\section{Chemical analysis}

Concentrations of Se in plant digestion samples and all soil extractions, and concentrations of $\mathrm{P}$ in $0.01 \mathrm{M} \mathrm{CaCl}_{2}$ and hot water extractions were measured using High Resolution ICP-MS (Thermo Scientific, Element2). Concentrations of $\mathrm{S}$ in $0.01 \mathrm{M} \mathrm{CaCl}_{2}$ and hot water extractions and $\mathrm{S}, \mathrm{P}, \mathrm{Fe}$ and $\mathrm{Al}$ in ammonium oxalate extraction were measured using ICP-AES (Thermo Scientific, Iris 
Table 3 Operational conditions of HPLC and High Resolution ICP-MS for Se speciation analysis in ammonium oxalate soil extractions

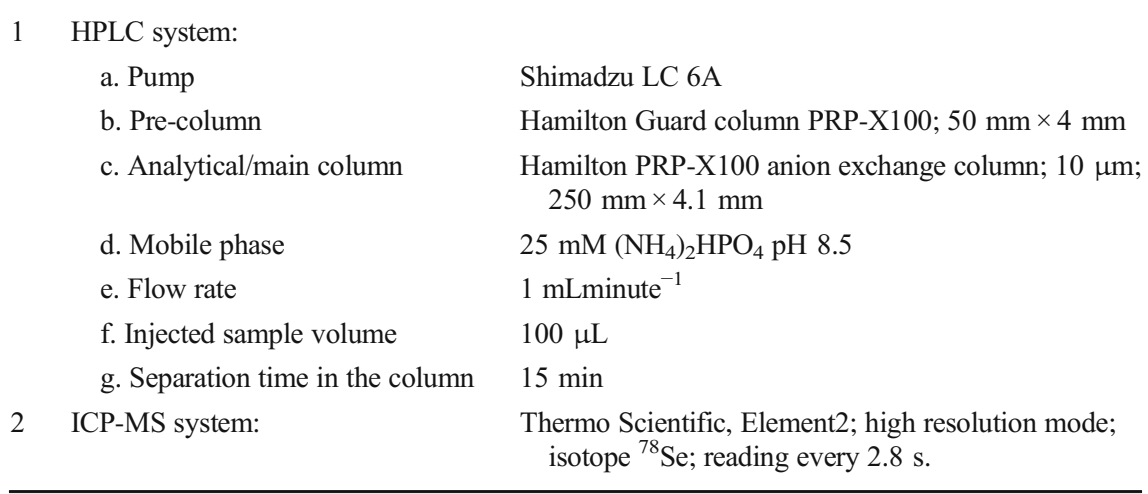

Advantage). Concentrations of DOC in $0.01 \mathrm{M} \mathrm{CaCl}_{2}$, $0.43 \mathrm{MHNO}_{3}$ and hot water extractions, soluble inorganic $\mathrm{N}$ and total soluble $\mathrm{N}$ in $0.01 \mathrm{M} \mathrm{CaCl}_{2}$ extraction, and ortho-phosphate $\mathrm{P}\left(\mathrm{P}_{-} \mathrm{PO}_{4}\right)$ in $0.01 M \mathrm{CaCl}_{2}$ and hot water extractions were measured using a segmented flow analyser (SFA) (3039 Skalar, the Netherlands). The UVabsorbance of the ammonium oxalate extracts was determined using UV-spectrophotometer (Genesys 10S Thermo Scientific). $\mathrm{pH}$ was measured using a $\mathrm{pH}$ meter (Radiometer Analytical PHM210) with a glass electrode (Beckman 511084). Total C and $\mathrm{N}$ in the soil samples were analysed using a CHN elementary analyser (Leco). Total organic matter content in the soil samples was analysed using near infrared spectroscopy (NIR). Total organic C content in the soil samples was calculated from the measured soil organic matter content assuming that soil organic matter contains $50 \%$ organic $\mathrm{C}$.

\section{Linear regression analysis}

Single and multiple linear regression analyses were performed to correlate Se content in the wheat shoots and soil parameters measured in order to identify soil parameters that determine Se content in wheat shoots. Since the Se contents in the wheat shoots were not normally distributed, the data were transformed into $\log (10)$ before used in the regression analyses.

\section{Results}

Total and extractable Se content in soils

Total Se content (aqua regia) in the arable land soils ranges from 0.22 up to $0.73 \mathrm{mg} \mathrm{kg}^{-1}$, which is mostly less than $0.6 \mathrm{mg} \mathrm{Se} \mathrm{kg}{ }^{-1}$ (Table 1). Gupta and Gupta (2000) suggested a threshold value of $0.6 \mathrm{mg} \mathrm{kg}^{-1}$ for Se deficient soils. Our previous study has also shown that about $75 \%$ of 83 soil samples taken from grasslands and other arable lands in the Netherlands contain less than $0.6 \mathrm{mg} \mathrm{Se} \mathrm{kg}{ }^{-1}$ (Supriatin et al. 2015b). The findings suggest that most of agricultural soils in the Netherlands are Se deficient. Other parts of Europe, such as Belgium, Sweden, Germany, Czech Republic, Spain (Mediterranean area), also have low total Se content in their soils i.e. mainly $<0.50 \mathrm{mg} \mathrm{kg}^{-1}$ (De Temmerman et al. 2014; Hartfiel and Bahners 1988; Johnsson 1992; Roca-Perez et al. 2010; Száková et al. 2015). Total Se (aqua regia) in soils used in this study is hardly correlated to amorphous Al-(hydr)oxide content $\left(\mathrm{R}^{2}=0.16\right.$, $p>0.05)$ and weakly correlated to soil organic matter content $\left(\mathrm{R}^{2}=0.26, p<0.05\right)$ and to amorphous Fe-(hydr)oxide content $\left(\mathrm{R}^{2}=0.51, p<0.001\right)$. In contrast, our previous study using 83 soil samples taken from grasslands and other arable lands in the Netherlands showed that the total Se (aqua regia) is strongly correlated with soil organic matter content and amorphous Fe- and Al-(hydr)oxide content (Supriatin et al. 2015b). This difference is probably due to a narrow range of soil organic matter content, amorphous $\mathrm{Fe}$ - and $\mathrm{Al}$-(hydr)oxide content, and total $\mathrm{Se}$ (aqua regia) content in the soils used in this study (Table 1). The fraction of inorganic Se (mainly selenite) in the soils is on average $3 \pm 3 \%$ of total Se (aqua regia) (Table 7; $n=15$ ), indicating that most of the Se is present in organic form, despite that only a weak correlation was found between total Se content and soil organic matter content.

The amount of Se measured in different extractions followed the order of aqua regia (224 to 
$734 \mu \mathrm{g} \mathrm{kg}^{-1}$ ) >ammonium oxalate (38 to $\left.146 \mu \mathrm{g} \mathrm{kg}^{-1}\right)>$ hot water $\left(6\right.$ to $\left.29 \mu \mathrm{g} \mathrm{kg}^{-1}\right) \geq 0.43 \mathrm{M}$ $\mathrm{HNO}_{3}$ ( 7 to $\left.32 \mu \mathrm{g} \mathrm{kg}^{-1}\right)>0.01 M \mathrm{CaCl}_{2}$ (1.2 to $6.0 \mu \mathrm{g} \mathrm{kg}^{-1}$ ) (Tables 1 and 6). Soluble Se concentration in $0.01 \mathrm{M} \mathrm{CaCl}_{2}$ extraction accounts for on average 1.0 $\pm 0.7 \%$ of total Se (aqua regia) (Table 1), slightly lower than that observed in the previous study for grassland soils $(1.5 \pm 0.6 \%)$ and other arable land soils (1.4 $\pm 0.6 \%$ ) (Supriatin et al. 2015b). The fraction of Se in other extractions is on average $4 \pm 2 \%$ in $0.43 \mathrm{MHNO}_{3}$; $5 \pm 2 \%$ in hot water; and $21 \pm 7 \%$ in ammonium oxalate (Table 6), comparable to that measured in previous study (Supriatin et al. 2015b). On average $85 \%$ of Se in ammonium oxalate extraction is organic Se and $15 \%$ is inorganic Se (mainly selenite) (Table $7 ; n=16$ ). Previous studies suggested that $\mathrm{Se}$ in $0.01 \mathrm{M} \mathrm{CaCl}_{2}$ and hot water extraction is mainly in organic Se form, whereas $0.43 \mathrm{MHNO}_{3}$ extracts mainly inorganic Se plus a small amount of organic Se (Supriatin et al. 2015a, b).

Selenium content in wheat shoots

Selenium content in the wheat shoots is between 7 and $101 \mu \mathrm{g} \mathrm{kg}^{-1}$ (plant dry weight), with a mean of $28 \mu \mathrm{g} \mathrm{kg}^{-1}(n=19)$ (Fig. 8). In general, Se content in the wheat shoots grown on clay soils with clay content $\geq 20 \%$ and $\mathrm{pH}>6$ is higher than that in the wheat shoots grown on other soil types (Fig. 1a). The variability of Se content in the wheat shoots grown on "other clay" soils is high due to that one wheat shoot sample (grown on a clay soil with clay content $18 \%$ and $\mathrm{pH}$ 7.30) contains $101 \mathrm{\mu g} \mathrm{kg}^{-1}$ Se whereas the other five samples (grown on clay soils with clay content 12 to $30 \%$ and $\mathrm{pH} 5.20$ to 7.30 ) contain about 12 to $40 \mu \mathrm{g} \mathrm{kg}^{-1} \mathrm{Se}$. Since the wheat shoots were harvested at the flowering stage, we do not have data of Se content in wheat grain. It has been shown that Se content in wheat grain is correlated to Se content in wheat stems or leaves, and that the grain Se content is largely similar to that in the wheat stems but much lower than the Se content in wheat leaves (Jiang et al. 2015). Therefore, we expect that Se content in wheat grain in our current study would be less than that measured in the shoots (i.e. 7 to $101 \mu \mathrm{g} \mathrm{kg}^{-1} \mathrm{Se}$ ).

A Se content in plants of 50 to $100 \mu \mathrm{g} \mathrm{Se} \mathrm{kg}^{-1}$ dry weight has been proposed as the minimum amount required for animal and human intake (Gardiner and Gorman 1963; Hawkesford and Zhao 2007). Previous studies showed that Se content in wheat grain grown on
41 Danish soils range between 4 and $67 \mu \mathrm{g} \mathrm{kg}^{-1}$, with an average of $20 \mu \mathrm{g} \mathrm{kg}^{-1}$ (Gissel-Nielsen 1975) and in the wheat grain grown on UK soils is on average between 25 and $33 \mu \mathrm{g} \mathrm{kg}^{-1}$ ( $n=85$ to 187 ) over 3 years of sampling (Adams et al. 2002). Total Se contents in Danish soils and UK soils are between 0.14 and $0.52 \mathrm{mg} \mathrm{kg}^{-1}$ (Hamdy and Gissel-Nielsen 1976 in Gupta and Gupta 2000) and on average $0.50 \mathrm{mg} \mathrm{kg}^{-1}$ (Adams et al. 2002), respectively, which are in a similar range as in the soils in our current study (Table 1). Based on these findings, we expect that without Se fertilizer application, Se content in wheat grain grown on the soils in our study would be mostly below the minimum amount of Se for animal and human intake, especially in the soils other than clay soil with a combination of clay content $\geq 20 \%$ and $\mathrm{pH}>6$ (Fig. 1a), indicating a generally low Se bioavailability in the arable soils in the Netherlands.

The yield of wheat shoots ranged from 2 to $9 \mathrm{~g}$ dry weight pot $^{-1}$ (Fig. 8a). Soil type had no effect on crop yield (Fig. 1b). Hardly any correlation between yield and Se content in the wheat shoots $\left(\mu \mathrm{g} \mathrm{Se} \mathrm{kg}^{-1}\right.$ dry biomass) was observed $\left(\mathrm{R}^{2}=0.001, p>0.05\right.$; Fig. $\left.8 \mathrm{a}\right)$, indicating that $\mathrm{Se}$ is not a limiting factor for plant growth. A lack of correlation between yield and Se content in Italian rye grass (Lolium multiflorum) was also observed in the study of Yläranta (1983). The variation in yield of wheat shoots among the different soils (around 4 times; Fig. 8a) is smaller than that in Se content (15 times; Fig. 8 a) or total Se uptake (17 times; Fig. $8 b$ ) in wheat shoots, and the absolute Se content in the wheat shoots (in $\mu \mathrm{g} \mathrm{Se} \mathrm{kg}{ }^{-1}$ dry biomass) correlates well with the total Se uptake per pot (in $\mu \mathrm{g} \mathrm{Se} \mathrm{pot}^{-1}$ ) $\left(\mathrm{R}^{2}=0.93, p<0.001\right.$; Fig. $\left.8 b\right)$. Therefore, for the purpose of comparison among soils, there is not much difference if the absolute Se content or total Se uptake is used.

\section{Regression model for Se uptake}

To identify which soil parameters are important in determining Se content in the wheat shoots, firstly single factor regression analysis between Se content in the wheat shoots and each individual soil parameter was performed (Table 4). Among the soil property parameters, $\mathrm{pH}$ measured in $0.01 \mathrm{M} \mathrm{CaCl}_{2}$ extraction ( $\mathrm{pH}$ $\mathrm{CaCl}_{2}$ ), $\mathrm{pH}$ in hot water extraction ( $\mathrm{pH}$-hot water) and clay content are positively correlated to Se content in the wheat shoots, whereas organic matter content and soil 
Fig. 1 a Selenium content and $\mathbf{b}$ Yield of wheat shoots as affected by soil type. The bars are means and the error bars are the standard deviations per soil type. * is an outlier
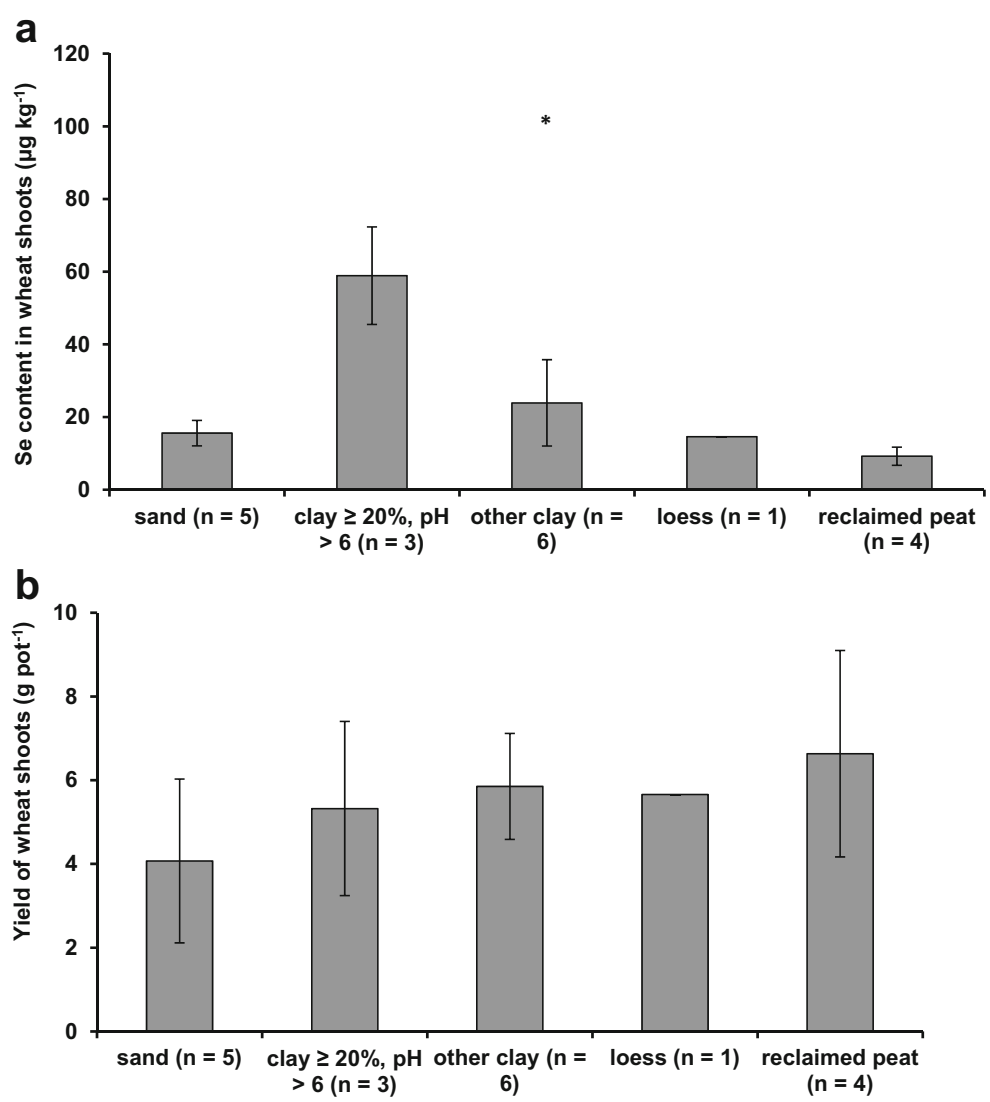

$\mathrm{C}: \mathrm{N}$ ratio are negatively correlated, and amorphous $\mathrm{Fe}-$ and Al-(hydr)oxide content are not correlated to Se content in the wheat shoots. Among Se concentrations measured in different extractions, Se in $0.01 \mathrm{M} \mathrm{CaCl}_{2}$ extraction $\left(\mathrm{Se}-\mathrm{CaCl}_{2}\right)$ and $\mathrm{Se}$ in hot water extraction (Se-hot water) are positively correlated to Se content in the wheat shoots, whereas total Se content (aqua regia) and total inorganic selenite content are negatively correlated, and Se in ammonium oxalate and $0.43 \mathrm{M}$ $\mathrm{HNO}_{3}$ extractions are not correlated to Se content in the wheat shoots. Besides, DOC and DON in $0.01 \mathrm{M}$ $\mathrm{CaCl}_{2}$ extraction (DOC-CaCl $\mathrm{C}_{2}$ and $\mathrm{DON}-\mathrm{CaCl}_{2}$, respectively) and DOC in hot water extraction (DOC-hot water) are negatively correlated to Se content in wheat shoots, whereas other soil parameters considered, such as $\mathrm{S}, \mathrm{P}$ and $\mathrm{PO}_{4}$ in $0.01 \mathrm{M} \mathrm{CaCl}_{2}$ and hot water extractions, and $\mathrm{S}$ and $\mathrm{P}$ in ammonium oxalate extraction are not correlated to Se content in the wheat shoots. Among the single soil parameters, soil $\mathrm{pH}$ explains most (about $60 \%$ ) of the variation of Se content in wheat shoots (Table 4 and Fig. 2), showing that Se content in wheat shoots increases with soil pH (Fig. 2).
Following the single parameter regression, multiple linear regression analysis was performed by combining two or more soil parameters. We included in this multiple regression the soil factors of $\mathrm{pH}-\mathrm{CaCl}_{2}, \mathrm{pH}-$ hot water, clay content, soil organic matter content, soil $\mathrm{C}: \mathrm{N}$ ratio, $\mathrm{Se}-\mathrm{CaCl}_{2}$, Se-hot water, total Se content (aqua regia), inorganic selenite content, DOC-CaCl 2 , DON$\mathrm{CaCl}_{2}$ and DOC-hot water, all of which have been found correlated with Se content in the wheat shoots (Table 4). For all combinations of two factors regression, the best regression model obtained includes $\mathrm{Se}-\mathrm{CaCl}_{2}$ and DOC$\mathrm{CaCl}_{2}$, which explains $85 \%$ (adjusted $\mathrm{R}^{2}=0.85$, $p<0.001)$ of the variability of Se content in the wheat shoots (Eq. 1 and Model 25 in Table 8). We have shown above that in general the Se content in the wheat shoots grown on clay soils with a combination of clay content $\geq 20 \%$ and $\mathrm{pH}>6$ is higher than that in the wheat shoots grown on other soil types (Fig. 1a). The two factors regression including clay content and $\mathrm{pH}-$ $\mathrm{CaCl}_{2}$ leads to an adjusted $\mathrm{R}^{2}$ of $0.58, p<0.001$ (Eq. 2 and Model 8 in Table 8). Extending the regression to three or four factors can only slightly raise the maximum 
Table 4 Regression parameters of the equation: $\log _{10}\left(\right.$ Se content in wheat shoots, $\left.\mu \mathrm{g} \mathrm{kg}{ }^{-1}\right)=\mathrm{a}+\mathrm{b}^{*} \log _{10}(\operatorname{soil}$ parameter $)(n=19)$

\begin{tabular}{|c|c|c|c|c|}
\hline Soil parameter & Intercept (a) & Coefficient (b) & $\mathrm{R}^{2}$ & $p$ value \\
\hline $\mathrm{pH}-\mathrm{CaCl}_{2}^{\mathrm{a}}$ & -0.16 & 0.24 & 0.60 & $<0.001$ \\
\hline pH-hot water ${ }^{\mathrm{a}}$ & -0.14 & 0.22 & 0.58 & $<0.001$ \\
\hline Clay $(\%)$ & 0.98 & 0.39 & 0.46 & $<0.01$ \\
\hline Organic matter $(\%)$ & 1.78 & -0.74 & 0.50 & $<0.001$ \\
\hline Soil C:N ratio & 2.99 & -1.49 & 0.41 & $<0.01$ \\
\hline Amorphous Fe-(hydr)oxide $\left(\mathrm{mg} \mathrm{kg}^{-1}\right)$ & 1.66 & -0.10 & 0.01 & $>0.05$ \\
\hline Amorphous Al-(hydr)oxide $\left(\mathrm{mg} \mathrm{kg}^{-1}\right)$ & 3.71 & -0.81 & 0.21 & 0.05 \\
\hline $\mathrm{Se}-\mathrm{CaCl}_{2}\left(\mu \mathrm{g} \mathrm{kg}^{-1}\right)$ & 0.79 & 1.12 & 0.45 & $<0.01$ \\
\hline $\mathrm{Se}-\mathrm{HNO}_{3}\left(\mu \mathrm{g} \mathrm{kg}^{-1}\right)$ & 2.14 & -0.75 & 0.21 & 0.05 \\
\hline Se-hot water $\left(\mu \mathrm{g} \mathrm{kg}^{-1}\right)$ & -0.04 & 1.09 & 0.22 & $<0.05$ \\
\hline Se-ammonium oxalate ${ }^{\mathrm{b}}\left(\mu \mathrm{g} \mathrm{kg}^{-1}\right)$ & 1.54 & -0.18 & 0.02 & $>0.05$ \\
\hline Total Se (aqua regia) ${ }^{\mathrm{b}}\left(\mu \mathrm{g} \mathrm{kg}^{-1}\right)$ & 4.15 & -1.10 & 0.30 & $<0.05$ \\
\hline Selenite $^{\mathrm{b}}\left(\mu \mathrm{g} \mathrm{kg}^{-1}\right)$ & 2.13 & -0.67 & 0.42 & $<0.05$ \\
\hline DOC-CaCl $2\left(\mathrm{mg} \mathrm{kg}^{-1}\right)$ & 3.77 & -1.35 & 0.51 & $<0.001$ \\
\hline DOC-hot water $\left(\mathrm{mg} \mathrm{kg}^{-1}\right)$ & 1.13 & -0.97 & 0.53 & $<0.001$ \\
\hline DON-CaCl $\left(\mathrm{mg} \mathrm{kg}^{-1}\right)$ & 1.88 & -0.60 & 0.34 & $<0.01$ \\
\hline $\mathrm{S}-\mathrm{CaCl}_{2}\left(\mathrm{mg} \mathrm{kg}^{-1}\right)$ & 1.60 & -0.18 & 0.12 & $>0.05$ \\
\hline S-hot water $\left(\mathrm{mg} \mathrm{kg}^{-1}\right)$ & 1.80 & -0.34 & 0.14 & $>0.05$ \\
\hline S-ammonium oxalate $\left(\mathrm{mg} \mathrm{kg}^{-1}\right)$ & 2.23 & -0.47 & 0.19 & $>0.05$ \\
\hline $\mathrm{P}-\mathrm{CaCl}_{2}\left(\mathrm{mg} \mathrm{kg}^{-1}\right)$ & 1.27 & 0.09 & 0.009 & $>0.05$ \\
\hline P-hot water $\left(\mathrm{mg} \mathrm{kg}^{-1}\right)$ & 1.74 & -0.33 & 0.08 & $>0.05$ \\
\hline P-ammonium oxalate $\left(\mathrm{mg} \mathrm{kg}^{-1}\right)$ & 2.44 & -0.42 & 0.03 & $>0.05$ \\
\hline $\mathrm{PO}_{4}-\mathrm{CaCl}_{2}\left(\mathrm{mg} \mathrm{kg}^{-1}\right)$ & 1.28 & 0.10 & 0.02 & $>0.05$ \\
\hline $\mathrm{PO}_{4}$-hot water $\left(\mathrm{mg} \mathrm{kg}^{-1}\right)$ & 1.43 & -0.12 & 0.02 & $>0.05$ \\
\hline
\end{tabular}

${ }^{\mathrm{a}} \mathrm{pH}$ is not converted into $\log _{10}$

${ }^{\mathrm{b}}$ The samples that have Se concentrations below the determination limit were not included in the regression analysis

adjusted $\mathrm{R}^{2}$ from 0.85 to 0.87 (Table 8 ), and since the benefit of including additional factors is relatively small we focus our further evaluation on the one factor and two factors regressions.

$\log \left(\mathrm{Se}-\right.$ wheat shoots, $\left.\mu \mathrm{g} \mathrm{kg}^{-1}\right)=3.09+1.01 \log \left(\mathrm{Se}_{-} \mathrm{CaCl}_{2}, \mu \mathrm{g} \mathrm{kg}^{-1}\right)-1.23 \mathrm{Log}\left(\mathrm{DOC}-\mathrm{CaCl}_{2}, \mathrm{mg} \mathrm{kg}^{-1}\right)$ Adj. $\mathbf{R}^{2}=0.85, p<0.001$

$\log \left(\mathrm{Se}^{-}\right.$wheat shoots, $\left.\mu \mathrm{g} \mathrm{kg}^{-1}\right)=0.07+0.19\left(\mathrm{pH}^{-} \mathrm{CaCl}_{2}\right)+\mathbf{0 . 1 5} \log (\operatorname{clay}, \%) \operatorname{Adj} . \mathbf{R}^{2}=\mathbf{0 . 5 8}, p<0.001$

Se-wheat shoots, $\mu \mathrm{g} \mathrm{kg}^{-1}=\mathbf{0 . 6 9}\left(\mathrm{Se}: \mathrm{DOC}-\mathrm{CaCl}_{2}, \mu \mathrm{gg}^{-1}\right) 8.39 \mathbf{R}^{2}=\mathbf{0 . 8 8}$ or Adj. $\mathbf{R}^{2}=0.87, p<0.001$

\section{Discussion}

Selenium to DOC ratio in $0.01 \mathrm{M} \mathrm{CaCl}_{2}$ extraction determines Se uptake in wheat shoots

Soluble Se and DOC in $0.01 \mathrm{MCaCl}_{2}$ extraction explain the majority (around $85 \%$ ) of Se variability in wheat shoots grown on low Se soils under controlled conditions (Eq. 1 and Model 25 in Table 8). This model can predict Se content in the wheat shoots quite well, however, when the measured Se content in the wheat shoots is above $60 \mu \mathrm{g} \mathrm{kg}^{-1}$, the model underestimates the measured values (Fig. 3). This model, which is based on the two major explanatory variables, can be further 
Fig. 2 Correlation between Se content in wheat shoots and soil $\mathrm{pH}$ measured in $0.01 \mathrm{M} \mathrm{CaCl}_{2}$ extraction $(n=19)$

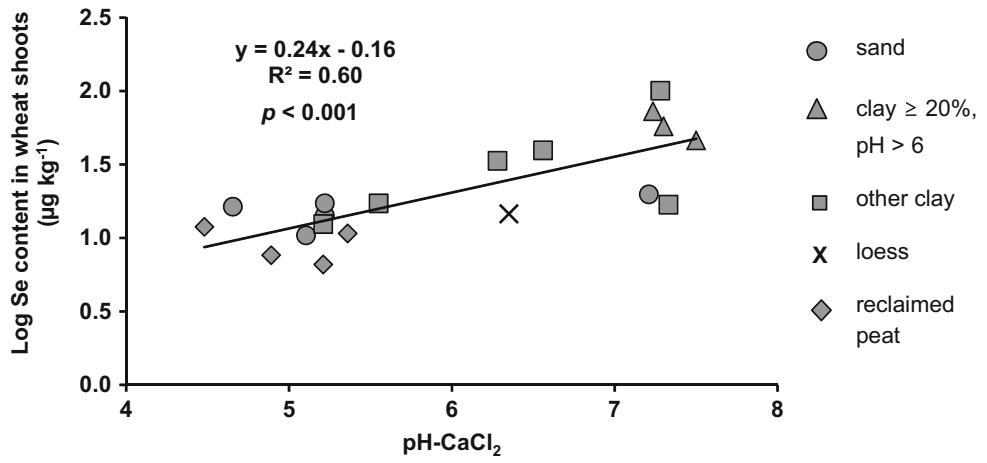

improved and reduced to a single factor regression model by replacing soluble Se and DOC in $0.01 \mathrm{M}$ $\mathrm{CaCl}_{2}$ extraction with the Se to DOC ratio in $0.01 \mathrm{M}$ $\mathrm{CaCl}_{2}$ extraction $\left(\mathrm{R}^{2}=0.88, p<0.001\right)$ (Eq. 3 and Fig. 7a), indicating that the richness of Se in dissolved organic matter (DOM) is a good predictor of bioavailable Se in low Se soils with predominantly organic Se.

Our observation that in general more Se was taken up in the wheat shoots grown on clay soils with clay content $\geq 20 \%$ and $\mathrm{pH}>6$ (Fig. 1a), is not directly reflected in the model in Eq. 1 (two factors model including $\mathrm{Se}$ and $\mathrm{DOC}$ in $\mathrm{CaCl}_{2}$ extraction) or in the single factor model with Se to DOC ratio in $\mathrm{CaCl}_{2}$ extraction (Eq. 3). The model in the Eq. 2, which includes clay content and $\mathrm{pH}-\mathrm{CaCl}_{2}$, has a lower predictive power $\left(\mathrm{R}^{2}=0.58, p<0.001\right)$ than the model in Eq. 1 $\left(\mathrm{R}^{2}=0.85, p<0.001\right)$. A closer examination shows that the higher Se uptake in the wheat shoots grown on clay soils with clay content $\geq 20 \%$ and $\mathrm{pH}>6$ is primarily related to the high Se to DOC ratio in $0.01 \mathrm{M} \mathrm{CaCl}_{2}$ extraction of these soils (Table 1). These findings indicate that bioavailability of Se in low Se soils dominated by organic Se is related to the solubility and quality of Se containing DOM in soil solution.
The Se and DOC concentrations in $0.01 M \mathrm{CaCl}_{2}$ extraction in the moist soil samples taken freshly from the fields have also been measured (Supriatin et al. 2015a). Consistent with the dried soils, Se to DOC ratio in $0.01 \mathrm{M} \mathrm{CaCl}_{2}$ extraction of the moist soils is also positively correlated to Se content in the wheat shoots $\left(\mathrm{R}^{2}=0.70, p<0.001 ; n=19\right)$, although the correlation for the moist soils is less strong than for dried soils $\left(\mathrm{R}^{2}=0.88, p<0.001\right.$; Eq. 3 and Fig. 7a). Previous study showed that an increase of both DOC (on average 2.5 to 2.7 fold) and Se (on average 2 to 4 fold) occurred in $0.01 \mathrm{M} \mathrm{CaCl}_{2}$ extraction upon soil drying, but the Se to DOC ratio remained quite stable (Supriatin et al. 2015a). However, the very low concentrations of soluble Se measured in $0.01 \mathrm{M} \mathrm{CaCl}_{2}$ extraction of moist soils can be a challenge to derive an indicator of Se bioavailability using the moist soil samples (Supriatin et al. 2015a).

In our preliminary study, selenite adsorption in several selected Dutch agricultural soil samples other than the soils used in the current study was measured by adding selenite (data not shown). By extrapolating the results of this adsorption experiment to the amount of selenite initially present in the soils used in the current study $\left(<40 \mu \mathrm{g} \mathrm{kg}^{-1}\right.$ ) (Table 7$)$, the $\mathrm{K}_{\mathrm{d}}$ values of selenite
Fig. 3 Comparison between the measured and calculated Se content in the wheat shoots grown in the pot experiment. The model used to calculate Se content in the wheat shoots includes soluble $\mathrm{Se}-\mathrm{CaCl}_{2}$ and $\mathrm{DOC}-\mathrm{CaCl}_{2}$ as soil parameters (Eq. 1 and Model 25 in Table 8). The line is $1: 1$ line at which the measured and calculated Se content in wheat shoots are equal

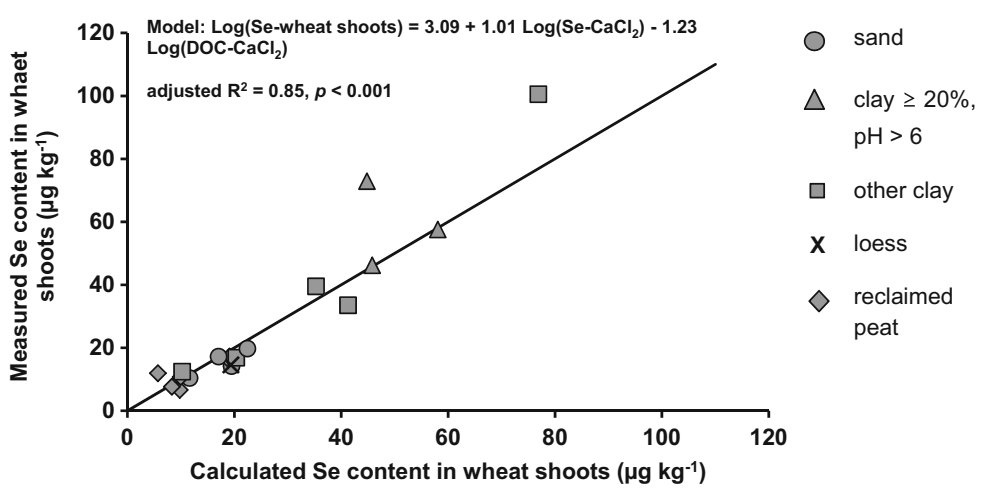


$\left(\mathrm{K}_{\mathrm{d}}=\right.$ ratio adsorbed selenite in $\mu \mathrm{g} \mathrm{kg}^{-1}$ : soluble selenite in $\mu \mathrm{g} \mathrm{L}^{-1}$ ) and amount of soluble selenite in $0.01 \mathrm{M}$ $\mathrm{CaCl}_{2}$ extraction were estimated for the soils under current study. These calculations suggest that the $\mathrm{K}_{\mathrm{d}}$ values for selenite in these soils are between 1500 and $4600 \mathrm{~kg} \mathrm{~L}^{-1}$ and that the soluble selenite concentration in $0.01 \mathrm{M} \mathrm{CaCl}_{2}$ are mainly $<10 \mathrm{ng} \mathrm{L}^{-1}\left(<0.1 \mu \mathrm{g} \mathrm{kg}^{-1}\right)$. This very low concentration explains why the soluble selenite was hardly measurable in the $0.01 \mathrm{M} \mathrm{CaCl}_{2}$ soil extraction (Supriatin et al. 2015a). The estimated concentration of soluble (inorganic) selenite accounts for mostly $<1 \%$ of total soluble Se measured in $0.01 \mathrm{M}$ $\mathrm{CaCl}_{2}$ extraction (1.2 to $6.0 \mu \mathrm{g} \mathrm{kg}^{-1}$; Table 1), which supports the above conclusion that the content of soluble Se-rich organic molecules determines the Se plant uptake.

Different forms of soluble organic Se, such as selenomethionine $\left(\mathrm{C}_{5} \mathrm{H}_{11} \mathrm{NO}_{2} \mathrm{Se}\right)$, methane seleninic acids $\left(\mathrm{CH}_{3} \mathrm{SeOOH}\right)$ and trimethyl selenium ion $\left(\left(\mathrm{CH}_{3}\right)_{3} \mathrm{Se}^{+}\right)$have been measured in soils (Abrams and Burau 1989; Abrams et al. 1990a; Stroud et al. 2012; Tolu et al. 2014; Yamada and Hattori 1989). Kikkert and Berkelaar (2013) have shown that selenium amino acids, such as selenomethionine, is more readily taken up by plants than selenocystine. Selenium content in selenium amino acids, such as selenocystine $\left(\mathrm{C}_{6} \mathrm{H}_{12} \mathrm{~N}_{2} \mathrm{O}_{4} \mathrm{Se}_{2}\right)$, selenocysteine $\left(\mathrm{C}_{3} \mathrm{H}_{7} \mathrm{NO}_{2} \mathrm{Se}\right)$ and selenomethionine $\left(\mathrm{C}_{5} \mathrm{H}_{11} \mathrm{NO}_{2} \mathrm{Se}\right)$, is high with a Se to $\mathrm{C}$ mass ratio of $2.2,2.2$ and $1.3 \mathrm{~g} \mathrm{~g}^{-1}$, respectively, which is in contrast to the much lower ratio of Se to DOC measured in the $\mathrm{CaCl}_{2}$ extraction (13 to $140 \mu \mathrm{g} \mathrm{g}^{-1}$; Table 1). If we take a Se to $\mathrm{C}$ ratio of $1.3 \mathrm{~g} \mathrm{~g}^{-1}$ based on selenomethionine as an assumed representative of Se-rich molecule in the $\mathrm{CaCl}_{2}$ extractions of the soils studied, and assume that the rest of DOM has a Se to C ratio of $10 \mu \mathrm{g} \mathrm{g}^{-1}$ (i.e. the overall Se to organic $\mathrm{C}$ ratio in bulk soil organic matter; Supriatin et al. 2015b), we can calculate the concentration of Serich molecule using the measured Se to DOC ratio in the $\mathrm{CaCl}_{2}$ extraction. This calculation leads to 0.28 to $5.51 \mu \mathrm{g} \mathrm{Se} \mathrm{kg}^{-1}$ soil of selenomethionine-like Se-rich organic molecule in the $\mathrm{CaCl}_{2}$ extraction of the soils studied, which would account for 24 to $93 \%$ of the measured total soluble $\mathrm{Se}$ in the $\mathrm{CaCl}_{2}$ extractions, but account for only 0.00024 to $0.01 \%$ of the measured total DOC. The fraction of Se-rich molecule calculated in this study is in similar range of selenomethionine fractions measured in water (on average $20 \%$ of soluble $\mathrm{Se}$ ) or $0.016 \mathrm{M} \mathrm{KH}_{2} \mathrm{PO}_{4}$ (52 to $83 \%$ of soluble Se) soil extractions from previous studies (Stroud et al. 2012; Tolu et al. 2014). A positive correlation between the amount of calculated Se-methionine in the $\mathrm{CaCl}_{2}$ extraction and Se content in the wheat shoots was found $\left(\mathrm{R}^{2}=0.63, p<0.001\right)$ (Fig. 4), which supports that the Se to DOC ratio in $\mathrm{CaCl}_{2}$ extraction can be considered as a measure of the amount of Se-rich organic molecule in the extraction.

Previous study of Supriatin et al. (2015a), however, found hardly any Se-rich small organic molecules $(<1 \mathrm{~nm})$ in the $\mathrm{CaCl}_{2}$ soil extraction, suggesting that the Se-rich organic molecules are probably associated with larger organic molecules, forming colloidal sized structures ( $1 \mathrm{~nm}$ to $0.45 \mu \mathrm{m})$. In addition, the Se to DOC ratios in the hydrophilic acid (Hy) and fulvic acid (FA) fractions of DOM in $\mathrm{CaCl}_{2}$ extraction are comparable, and the ratio of Se to DOC for both the Hy and FA fractions increases with $\mathrm{pH}$, especially in the soil samples from potato fields (Supriatin et al. 2015a), which supports the idea that most of Se-rich molecules are probably associated with colloidal sized Hy and FA molecules. A correlation analysis using Se to organic $\mathrm{C}$ ratio of $\mathrm{Hy}$ and FA fractions of DOM in $0.01 \mathrm{M} \mathrm{CaCl}_{2}$ extraction of soil samples taken from the same fields as used in this study ( $n=8)$ (Supriatin et al. 2015a) showed that Se content in the wheat shoots is strongly positively correlated with $\mathrm{Se}$ to organic $\mathrm{C}$ ratio of the Hy fraction $\left(\mathrm{R}^{2}=0.93, p<0.001\right)$ and less strongly correlated to Se to organic $C$ ratio of the FA fraction $\left(R^{2}=0.74\right.$, $p<0.05$ ). These findings indicate that the plant Se uptake is probably more influenced by Se-rich compounds in the more rapidly degradable Hy fraction than the less easily degradable FA fraction.

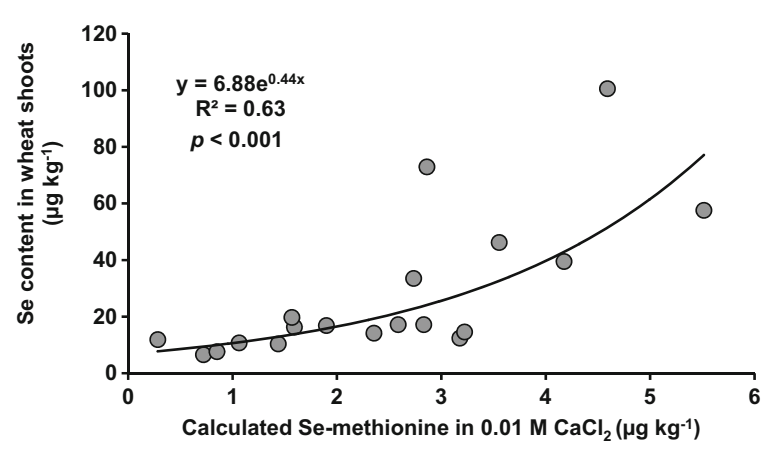

Fig. 4 Relationship between Se uptake in wheat shoots and calculated selenomethionine-like Se-rich organic molecule in the $\mathrm{CaCl}_{2}$ extraction estimated from the measured Se to DOC ratio in $\mathrm{CaCl}_{2}$ extraction 
Soil properties determining Se to DOC ratio in $0.01 \mathrm{M}$ $\mathrm{CaCl}_{2}$ extraction and $\mathrm{Se}$ in wheat shoot

The above results showed that soluble Se and DOC in $0.01 \mathrm{MCaCl}_{2}$ extraction, which are reflected by the Se to DOC ratio in $\mathrm{CaCl}_{2}$ extraction, are the main soil parameters determining Se uptake in the wheat shoots (Eqs. 1 and 3), suggesting that Se uptake in the wheat shoots is not only related to solution Se concentration but also to the Se speciation in the solution. To further explore the basic soil properties that can potentially determine the concentration and speciation of soluble Se, their correlation to soluble Se and Se to DOC ratio in $0.01 \mathrm{M} \mathrm{CaCl}_{2}$ extractions is investigated and discussed below. Both $\mathrm{pH}-$ $\mathrm{CaCl}_{2}$ and clay content are positively correlated to soluble $\mathrm{Se}$ and Se to DOC ratio, whereas organic matter content and soil $\mathrm{C}: \mathrm{N}$ ratio are negatively correlated (Table 5). Among these soil parameters, soil $\mathrm{pH}$ correlates most strongly with Se to DOC ratio $\left(\mathrm{R}^{2}=0.66\right.$, $p<0.001)$, but correlates the least with soluble Se $\left(\mathrm{R}^{2}=0.26, p<0.05\right)$ (Table 5), indicating that the soil $\mathrm{pH}$ is the primary factor that controls the solubility of Se-rich DOM. These findings correspond to our observations that $\mathrm{pH}$, clay content, soil organic matter content and soil C:N ratio are also significantly correlated with $\mathrm{Se}$ content in the wheat shoots, and that soil $\mathrm{pH}$ is the single factor that correlates most strongly with Se content in wheat shoots $\left(\mathrm{R}^{2}=0.58\right.$ to $\left.0.60, p<0.001\right)$ (Table 4$)$.

The amount of Se-rich DOM and Se content in the wheat shoots increase with $\mathrm{pH}$ (Tables 4 and 5 and Figs. 2 and 9a), consistent with previous studies that have shown the solubility of Se-containing organic matter increases with pH (Gustafsson and Johnsson 1994; Yanai et al. 2015). In addition to controlling the solubility of Secontaining organic matter, we expect that $\mathrm{pH}$ also plays a role in the mineralization of soluble organic Se (Fig. 5). The soluble organic Se, which may not be directly available for plant uptake when in colloidal form, is likely to be mineralized into soluble inorganic Se (selenate or selenite) or soluble small organic Se molecules that are available for plant uptake (Fig. 5). Curtin et al. (1998) suggested that mineralization of soil organic matter increased with an increase of soil pH from 5.7 to 7.3. Further, the soluble Se and Se to DOC ratio in $0.01 \mathrm{M}$ $\mathrm{CaCl}_{2}$ extraction, as well as Se content in the wheat shoots, are increased at a low soil C:N ratio (Tables 4 and 5), suggesting that the quality of solid soil organic matter strongly influences the amount of Se-rich DOM (Fig. 5). Our previous studies indicated that Se in both the soil solid phase and soil solution is mainly present as organic Se (Supriatin et al. 2015a; Supriatin et al. 2015b), and we expect, therefore, that mineralization of the organic Se controls the solubility and bioavailability of Se in these soils (Fig. 5). A low soil C:N ratio is related to both a relatively high Se content in soil organic matter (Fig. 6e) and to some extent a likely faster mineralization of soil organic matter (Post et al. 1985; Zech et al. 1997). In addition, soluble $\mathrm{Se}$ and $\mathrm{Se}$ to DOC ratio in $0.01 \mathrm{M}$ $\mathrm{CaCl}_{2}$ extraction and Se uptake in the wheat shoots have shown a positive correlation with clay content and a negative correlation with soil organic matter content (Tables 4 and 5). These correlations may be caused by the fact that clay and soil organic matter content are correlated with soil $\mathrm{C}: \mathrm{N}$ ratio $\left(\mathrm{R}^{2}=0.62, p<0.001\right.$ and $\mathrm{R}^{2}=0.42, p<0.01$ for the correlations between soil C:N ratio and clay content or soil $\mathrm{C}: \mathrm{N}$ ratio and organic matter content, respectively) and $\mathrm{pH}\left(\mathrm{R}^{2}=0.39, p<0.01\right.$ and $\mathrm{R}^{2}=0.40, p<0.01$ for the correlations between $\mathrm{pH}$ and clay content or $\mathrm{pH}$ and organic matter content, respectively) of these soils. Homann et al. (2007) indicated that the association of soil $\mathrm{N}$ with clay is stronger than that of soil organic $\mathrm{C}$ with clay, which results in a decrease of soil $\mathrm{C}: \mathrm{N}$ ratio with an increase of clay content as found in this study (data not shown). On the other hand, a positive

Table 5 Single factor linear regression between Se concentration or Se to DOC ratio in $0.01 \mathrm{MCaCl}_{2}$ extraction and basic soil properties $(n=19)$

\begin{tabular}{|c|c|c|c|c|c|c|c|c|}
\hline \multirow[t]{2}{*}{ Soil parameter } & \multicolumn{4}{|c|}{$\mathrm{Se}-\mathrm{CaCl}_{2}\left(\mu \mathrm{g} \mathrm{kg}^{-1}\right)=\mathrm{a}+\mathrm{b}^{*}$ soil parameter } & \multicolumn{4}{|c|}{$\begin{array}{l}\log _{10}(\text { ratio Se:DOC-CaCl } \\
\left.=a \mathrm{~g} \mathrm{~g}^{-1}\right) \\
=\mathrm{a}+\mathrm{Log}_{10}(\text { soil parameter })\end{array}$} \\
\hline & Intercept (a) & Coefficient (b) & $\mathrm{R}^{2}$ & $p$ value & Intercept (a) & Coefficient (b) & $\mathrm{R}^{2}$ & $p$ value \\
\hline $\mathrm{pH}-\mathrm{CaCl}_{2}$ & -0.78 & 0.66 & 0.26 & $<0.05$ & 0.35 & 0.21 & 0.66 & $<0.001$ \\
\hline Clay $(\%)$ & 2.11 & 0.09 & 0.53 & $<0.001$ & 1.37 & 0.32 & 0.44 & $<0.01$ \\
\hline Organic matter $(\%)$ & 4.18 & -0.17 & 0.29 & $<0.05$ & 2.08 & -0.69 & 0.62 & $<0.001$ \\
\hline Soil C:N ratio & 6.05 & -0.20 & 0.52 & $<0.001$ & 3.20 & -1.38 & 0.51 & $<0.001$ \\
\hline Amorphous Fe-(hydr)oxide (mg kg$\left.{ }^{-1}\right)$ & 3.19 & $4.28 * 10^{-6}$ & $9 * 10^{-5}$ & $>0.05$ & 2.06 & -0.12 & 0.02 & $>0.05$ \\
\hline
\end{tabular}




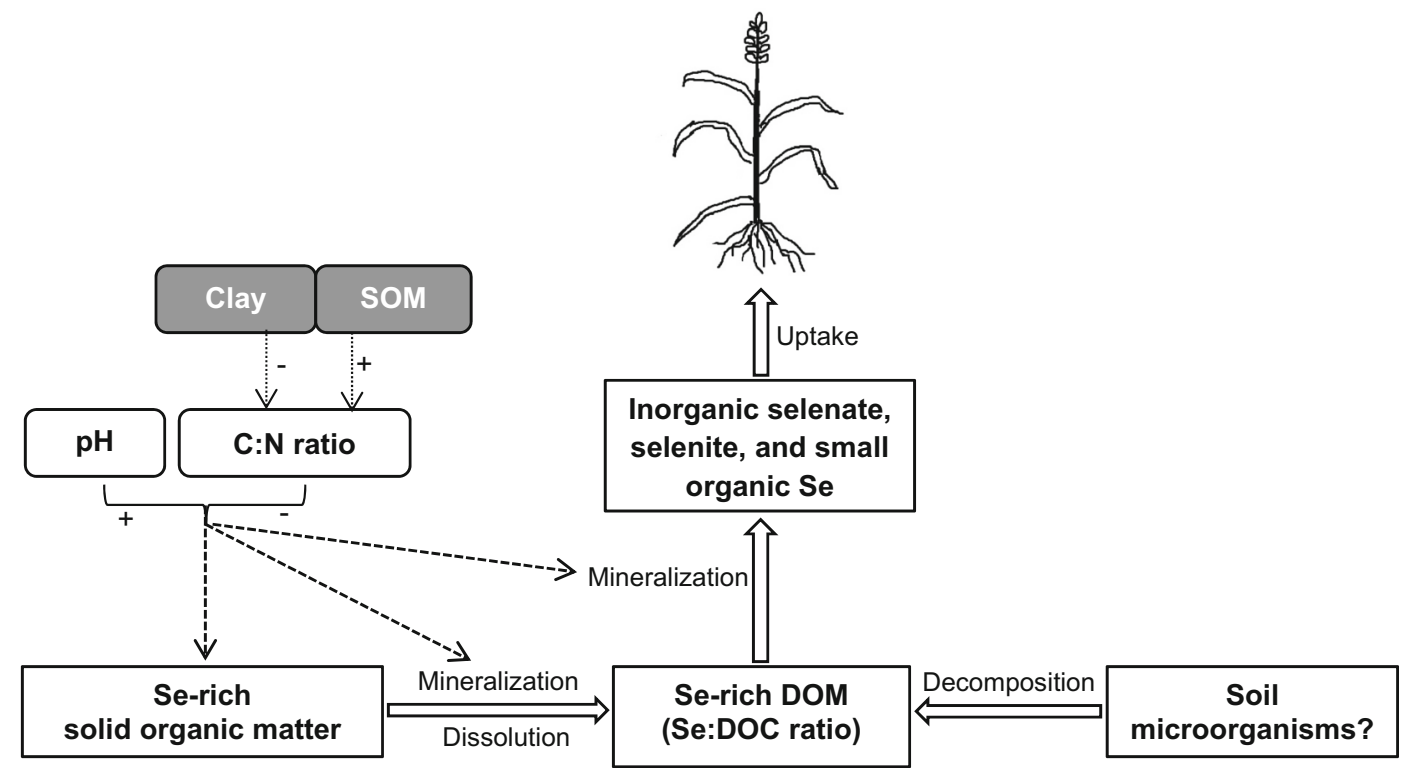

Fig. 5 Schematic pathways between Se in the soil solid phase, soil solution, and plants, and the basic soil properties influence these processes. In soils that contain low total Se with predominantly organic Se, Se-rich organic matter in the soil solid phase is released into the soil solution upon mineralization/dissolution. The decay of soil microorganisms may also contribute to Se-rich DOM. The Serich DOM can either be directly taken up by plants (in case of Seamino acids), or after being mineralized into chemical forms that are directly available (selenate, selenite, small organic Se). The amount

correlation between soil organic matter content and soil $\mathrm{C}: \mathrm{N}$ ratio was found (data not shown), reflecting a decline of the quality of soil organic matter (i.e. increase of soil $\mathrm{C}: \mathrm{N}$ ratio) in high organic matter soils.

Mass balance estimation

Selenium uptake in the wheat shoots is in the range of 0.03 to $0.59 \mu \mathrm{g} \mathrm{Se} \operatorname{pot}^{-1}$ (Fig. 8b). If we assume that the dissolved Se concentration in the soil pore water during the pot experiment is the same as that measured in the $0.01 \mathrm{M} \mathrm{CaCl}_{2}$ extraction ( 0.12 to $0.60 \mu \mathrm{g} \mathrm{L}^{-1}$; Table 1 ), taking into account the soil water content of the pot experiment (230 to $504 \mathrm{~mL} \mathrm{pot}^{-1}$ ), the dissolved Se in the soils used during the pot experiment is 0.04 to $0.24 \mu \mathrm{g} \mathrm{Se} \operatorname{pot}^{-1}$. When calculated in this way, the amount of Se taken up by wheat shoots accounts for 37 to $439 \%$ or about 0.4 to 4 times the dissolved Se in the pore water for the whole 53 days of wheat growth. However, it has been shown that the soluble Se extracted in $0.01 \mathrm{M} \mathrm{CaCl}_{2}$ of moist potato field soils as used in this study is 2 to 4 times lower than that measured in the of Se-rich DOM can be measured as the Se:DOC ratio in soil solution. $\mathrm{pH}$ has a positive, and soil C:N ratio has a negative effect on the amount of Se-rich solid organic matter, the mineralization/ dissolution of solid organic Se into soluble organic Se, and the mineralization of soluble organic Se. Clay content has a positive correlation, and soil organic matter content has a negative correlation with Se bioavailability, probably through its correlation with soil C:N ratio. Soil C:N ratio is negatively related to clay content and positively related to soil organic matter content.

same extraction using the dried soils (Supriatin et al. 2015a). Therefore, we expect that the dissolved Se concentration in the pore water during the pot experiment is less than that estimated above based on soluble Se measured in the $\mathrm{CaCl}_{2}$ extraction of dried soils. When assuming that the dissolved Se concentration in the pore water is the same as that measured in the $\mathrm{CaCl}_{2}$ extraction of the moist soils (0.04 to $0.48 \mu \mathrm{g} \mathrm{L}^{-1}$; Supriatin et al. 2015a), the total amount of Se taken up in the wheat shoots is 0.8 to 14 times the dissolved Se in the pore water. These values can be higher if Se taken up by the wheat roots and lost due to possible phytovolatilization are also included (Zayed et al. 1998).

The above calculation shows that to supply the amount of Se taken up by wheat during the pot experiment the dissolved Se in the pore water needs to be replenished by about 0.8 to 14 times within the 53 days period, corresponding to a total turn-over time of about 4 to 67 days. It has been shown that the turnover of free amino acids in soil through microbial mineralization is very fast (within a few hours) (Jones and Kielland 2002). The mineralization of the colloidal sized organic Se might be slower than the free 
amino acids. Nevertheless, up to $40 \%$ of DOM in soil solution can be mineralized within a period of days to a few months (Kalbitz et al. 2000). The amount of Se taken up in the wheat shoots is only 0.008 to $0.38 \%$ of total Se (aqua regia) in soils. On the other hand, the amount of labile organic Se as extracted in hot water accounts for on average $5 \%$ of total Se (aqua regia) (Table 6), which is much higher than the Se amount taken up by wheat shoots. The labile organic matter extracted in hot water is relatively rich in Se (Supriatin et al. 2015b), which may represent the Se-rich solid organic matter in soils (Fig. 5). The above simplified calculations show that the amount of Se generated during the mineralization of Se-rich solid and dissolved organic matter is potentially sufficient to explain the amount of Se taken up by wheat shoots (Fig. 5).

Selenium to organic $\mathrm{C}$ ratio in different extractions

The results above showed that among other soil properties, soil $\mathrm{pH}$ correlates most strongly with both Se to organic $\mathrm{C}$ ratio in $0.01 \mathrm{M} \mathrm{CaCl}_{2}$ extraction and Se uptake in the wheat shoots (Tables 4 and 5 and Figs. 2 and 9a). In addition to soil $\mathrm{pH}$, soil $\mathrm{C}: \mathrm{N}$ ratio is also related to both Se to organic $\mathrm{C}$ ratio in $0.01 \mathrm{M} \mathrm{CaCl}_{2}$ extraction and Se uptake in the wheat shoots (Tables 4 and 5 and Fig. 6a). Below, a further analysis of the correlation between soil $\mathrm{pH}$ or soil organic matter quality (i.e. soil $\mathrm{C}: \mathrm{N}$ ratio) and Se to organic $\mathrm{C}$ ratio in different extractions was performed. Moreover, correlation analysis between the Se to organic $\mathrm{C}$ ratio in different extractions and Se uptake in the wheat shoots was carried out.

These correlation analyses show that the soil $\mathrm{pH}$ is strongly positively correlated to the Se to organic $\mathrm{C}$ ratio in $0.01 \mathrm{M} \mathrm{CaCl}_{2}$ and hot water extractions $\left(\mathrm{R}^{2}=0.66\right.$, $p<0.001$ and $\mathrm{R}^{2}=0.69, p<0.001$, respectively), but weakly correlated to the $\mathrm{Se}$ to organic $\mathrm{C}$ ratio in $0.43 \mathrm{MHNO}_{3}$ and ammonium oxalate extractions and aqua regia digestion $\left(\mathrm{R}^{2}=0.26\right.$ to 0.39$)$ (Figs. 9a and b), indicating that $\mathrm{pH}$ influences the amount of Se-rich organic matter mainly in the soluble and labile fractions. On the other hand, in general, soil C: $\mathrm{N}$ ratio is strongly negatively correlated with the $\mathrm{Se}$ to organic $\mathrm{C}$ ratio in all the soil extractions $\left(\mathrm{R}^{2}=0.51\right.$ to $\left.0.79, p<0.001\right)$ (Fig. 6), suggesting that at a low soil $\mathrm{C}: \mathrm{N}$ ratio soil organic matter is richer in Se than at a high soil $\mathrm{C}: \mathrm{N}$ ratio, regardless of the different pools of soil organic matter (soluble, acid extractable, labile, oxide associated or bulk of organic matter). These findings suggest that both the soil $\mathrm{pH}$ and soil organic matter quality (i.e. soil
$\mathrm{C}: \mathrm{N}$ ratio) control the content of Se-rich organic matter in the soluble $\left(0.01 \mathrm{M} \mathrm{CaCl}_{2}\right.$ extraction) and labile (hot water extraction) organic matter pools, whereas in the rest of the organic matter pools $\left(\mathrm{HNO}_{3}\right.$ and ammonium oxalate extractions and aqua regia digestion), the soil organic matter quality (i.e. soil C:N ratio) has a larger influence on the Se to organic $\mathrm{C}$ ratio than the soil $\mathrm{pH}$ (Figs. 6 and 9).

As a comparison with DOC, the amount of DON in the $\mathrm{CaCl}_{2}$ extraction was also measured, which range from 2 to $33 \mathrm{mg} \mathrm{N} \mathrm{kg}^{-1}$ soil. The ratio of Se to DON in $\mathrm{CaCl}_{2}$ extraction is between 42 and $1578 \mu \mathrm{g} \mathrm{g}^{-1}$, with an average of $488 \mu \mathrm{g} \mathrm{g}^{-1}$, which is substantially higher than the average ratio of total Se (aqua regia) to total $\mathrm{N}$ in these soils, i.e. $189 \mu \mathrm{g} \mathrm{g}^{-1}$. Despite the observed correlation between the soil C:N ratio and Se to DOC ratio in the $\mathrm{CaCl}_{2}$ extraction (and also in other extractions) (Fig. 6), only a weak correlation occurs between soil C:N ratio and DON concentration in $\mathrm{CaCl}_{2}$ extraction $\left(\mathrm{R}^{2}=0.22, p<0.05\right)$, and hardly any correlations between soil $\mathrm{C}: \mathrm{N}$ ratio and $\mathrm{DOC}$ to $\mathrm{DON}$ ratio in $\mathrm{CaCl}_{2}$ extraction (DOC:DON ratio $=2$ to 28$)\left(\mathrm{R}^{2}=0.09\right.$, $p>0.05)$, between DON and soluble Se concentration in $\mathrm{CaCl}_{2}$ extraction $\left(\mathrm{R}^{2}=0.10, p>0.05\right)$, and between DOC to DON ratio and Se to DOC ratio in $\mathrm{CaCl}_{2}$ extraction $\left(\mathrm{R}^{2}=0.01, p>0.05\right)$. These results indicate that although the overall soil organic matter quality (i.e. soil $\mathrm{C}: \mathrm{N}$ ratio) is an important factor determining the amount of soluble Se-rich organic matter (i.e. ratio of soluble Se to DOC in $\mathrm{CaCl}_{2}$ extraction) (Fig. 6a), the amount of soluble Se-rich organic molecules is not directly related to the solubility of N-containing organic molecules in general.

Among the Se to organic $\mathrm{C}$ ratios in all the soil extractions, Se to organic $\mathrm{C}$ ratio in $0.01 \mathrm{M} \mathrm{CaCl}_{2}$ extraction correlates most strongly with Se content in the wheat shoots $\left(\mathrm{R}^{2}=0.88, p<0.001\right.$; Fig. 7$)$. On the other hand, Se to organic $\mathrm{C}$ ratio in other extractions $\left(0.43 \mathrm{M} \mathrm{HNO}_{3}\right.$, hot water and ammonium oxalate extractions and aqua regia digestion) are weakly correlated with Se uptake in the wheat shoots $\left(R^{2}=0.15\right.$ to 0.40 ; Fig. 7). These findings confirm that the amount of Se-rich DOM in soil solution is the main limiting factor for Se plant uptake.

Implication of the regression uptake model for prediction of Se bioavailability in other soil samples

The results of current study apply to soil samples that have low level of Se (total 0.22 to $0.73 \mathrm{mg} \mathrm{kg}^{-1}$ and 
Fig. 6 Correlations between soil $\mathrm{C}: \mathrm{N}$ ratio and Se to organic $\mathrm{C}$ ratio in (a) $0.01 \mathrm{M} \mathrm{CaCl}_{2}$, (b) $0.43 \mathrm{MHNO}_{3}$, (c) hot water, (d) ammonium oxalate (three samples with Se concentrations in the extraction below the determination limit were not included in the correlation) and (e) $\mathrm{Se}$ (aqua regia) to total organic $\mathrm{C}$ ratio (one sample with $\mathrm{Se}$ concentration in aqua regia below the determination limit was not included in the correlation)
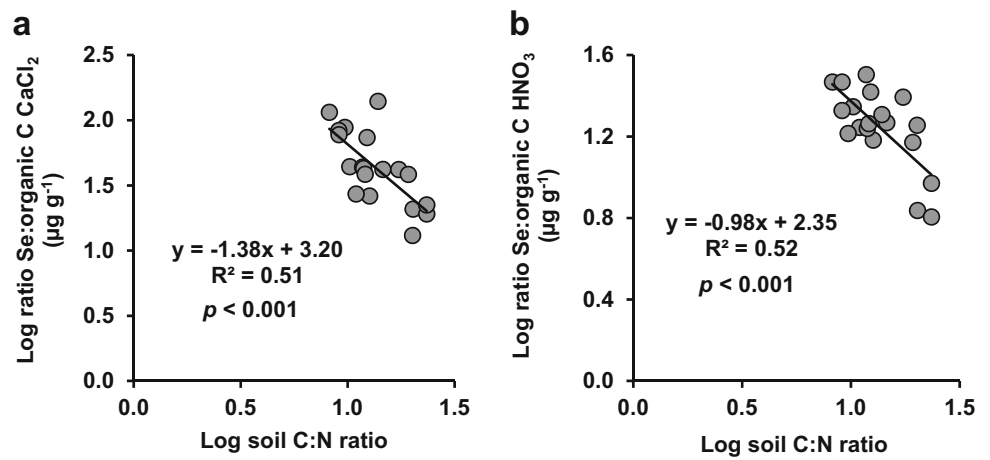

C
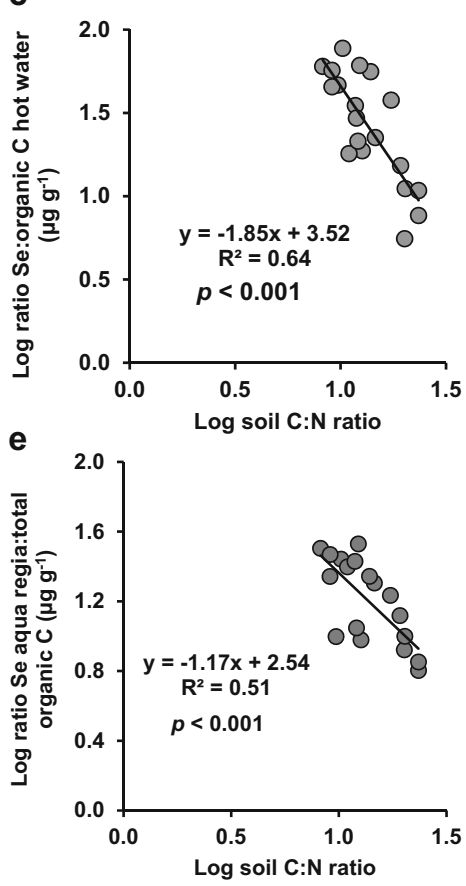

d

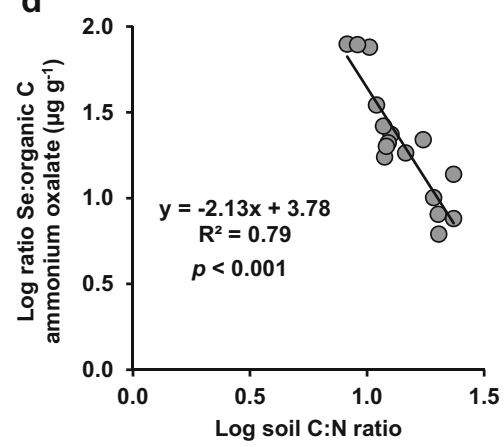

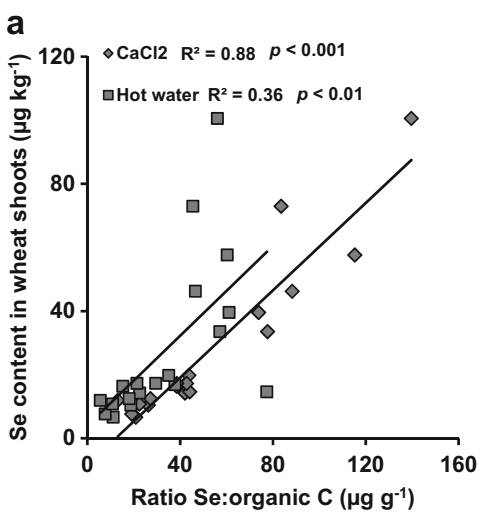

Fig. 7 Correlation between Se content in wheat shoots and Se to organic $\mathrm{C}$ ratio in (a) $0.01 \mathrm{M} \mathrm{CaCl}_{2}$ and hot water extractions and (b) $0.43 \mathrm{MHNO}_{3}$, ammonium oxalate and total content (Se aqua regia:total organic $\mathrm{C}$ ) (three samples in ammonium oxalate b

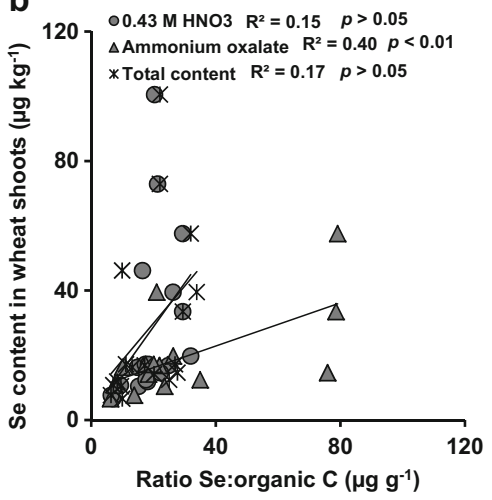

extraction and one sample in aqua regia digestion with Se concentrations in the extractions below the determination limit were not included in the correlation) 
soluble Se 0.12 to $0.60 \mu \mathrm{g} \mathrm{L}{ }^{-1}$ ) with predominantly organic Se, and with a low amount of DOC (3.5 to $18.4 \mathrm{mg} \mathrm{L}^{-1}$ ) (Table 1). In a previous study we have found that the Se to DOC ratio in $0.01 \mathrm{M} \mathrm{CaCl}_{2}$ extraction of the majority of (dried) potato field soils used in the current study (on average $64 \pm 33 \mu \mathrm{g} \mathrm{g}^{-1} ; n=16$ ) is higher than that in similar extraction of (dried) soils from grassland fields ( $34 \pm 13 \mu \mathrm{g} \mathrm{g}^{-1} ; n=27$ ) and maize fields ( $\left.30 \pm 16 \mu \mathrm{g} \mathrm{g}^{-1} ; n=15\right)$, and in general the grassland soils $\left(0.21\right.$ to $4.02 \mu \mathrm{g} \mathrm{L}^{-1}$ for Se and 5.5 to $93.9 \mathrm{mg} \mathrm{L}^{-1}$ for DOC) and maize field soils ( 0.26 to $1.13 \mu \mathrm{g} \mathrm{L}^{-1}$ for Se and 11.2 to $53.9 \mathrm{mg} \mathrm{L}^{-1}$ for DOC) have a higher level of soluble Se and DOC in $0.01 \mathrm{M}$ $\mathrm{CaCl}_{2}$ extraction than those in potato field soils (Supriatin et al. 2015a). By Including three additional soil samples, the average Se to DOC ratio in $0.01 \mathrm{M}$ $\mathrm{CaCl}_{2}$ extraction of (dried) potato field soil samples used in the current study is $53 \pm 35 \mu \mathrm{g} \mathrm{g}^{-1}(n=19$; Table 1). These results indicate that the dissolved organic matter in potato field soils is richer in Se than that in grassland soils and maize field soils, and the dissolved organic matter in grassland soils contain similar amount of Se as that in maize field soils. Further research is needed to evaluate the validity of the Se uptake model derived in this study in other soils (i.e. grassland soils and maize field soils) with different quality of Secontaining DOM (i.e. lower Se to DOC ratio).

\section{Conclusions}

Total Se content (aqua regia) in the potato field soils is in the range of 0.22 to $0.73 \mathrm{mg} \mathrm{kg}^{-1}$, of which a small fraction (on average $3 \pm 3 \%$ of total $\mathrm{Se}$ ) is present as inorganic Se (mainly selenite) and the majority is in organic form. Soluble Se in $0.01 \mathrm{MCaCl}_{2}$ extraction is between 1.2 and $6.0 \mu \mathrm{g} \mathrm{kg}^{-1}$ and accounts for on average $1.0 \pm 0.7 \%$ of total Se. The soluble Se is mainly present as colloidal organic Se, whereas inorganic selenate, selenite, and small organic Se were hardly measurable. The Se content in the wheat shoots grown on these low total and soluble Se soils was found to be between 7 and $101 \mathrm{\mu g} \mathrm{kg}^{-1}$ (plant dry weight), with an average of $28 \mu \mathrm{g} \mathrm{kg}^{-1}$. In general, Se content in the wheat shoots grown on clay soils with a combination of clay content $\geq 20 \%$ and $\mathrm{pH}>6$ is higher compared to that in the wheat shoots grown on other soil types (i.e. sand, "other clay", loess and reclaimed peat soils).
A regression uptake model developed from these data shows that around $88 \%$ of variability of Se uptake in the wheat shoots grown under controlled conditions can be explained by the Se to DOC ratio in $0.01 \mathrm{M} \mathrm{CaCl}_{2}$ extraction, indicating that Se-rich DOM is the main source of bioavailable Se in these low Se soils with predominantly organic Se. The Se content in the wheat shoots is particularly strongly and positively correlated with Se to organic $\mathrm{C}$ ratio of the hydrophilic fraction of DOM in $0.01 \mathrm{M}$ $\mathrm{CaCl}_{2}$ extraction $\left(\mathrm{R}^{2}=0.93, p<0.001\right)$, suggesting that Se-rich compounds present in the easily degradable DOM fraction control Se bioavailability. Soil $\mathrm{pH}, \mathrm{C}: \mathrm{N}$ ratio, clay content and organic matter content have been identified as the major soil properties determining the Se to DOC ratio in $0.01 \mathrm{M} \mathrm{CaCl}_{2}$ extraction. The Se to DOC ratio in $0.01 \mathrm{M} \mathrm{CaCl}_{2}$ extraction increased towards high $\mathrm{pH}$, high clay content, low soil $\mathrm{C}: \mathrm{N}$ ratio and low soil organic matter content. Among these soil properties, soil $\mathrm{pH}$ correlates most strongly with Se to DOC ratio in $0.01 \mathrm{M} \mathrm{CaCl}_{2}$ extraction $\left(\mathrm{R}^{2}=0.66, p<0.001\right)$ and $\mathrm{Se}$ uptake in wheat shoots $\left(\mathrm{R}^{2}=0.60, p<0.001\right)$. In addition to soil $\mathrm{pH}$, our findings suggest that soil organic matter quality (i.e. soil $\mathrm{C}: \mathrm{N}$ ratio) controls to a large extent the amount and release of Se-rich organic molecules from the soil solid phase to soil solution and subsequent uptake.

The results of this study suggest that Se bioavailability in low Se soils with predominantly organic Se is determined by the solubility of Se-containing DOM in soil solution (i.e. soluble organic Se). Further research is recommended to validate the regression uptake model for prediction of Se bioavailability in soil samples from other land uses with different quality of soil organic matter (i.e. lower soluble Se to DOC ratio).

Acknowledgments The research was funded by STW (Stichting Technische Wetenschappen), the Netherlands under the project "Micronutrient Management for Sustainable Agriculture and Environment: A New Innovative Approach" (project number 10707). We thank Nutrient Management Institute, the Netherlands, which collected the soil samples from the fields for further use in the pot experiment. We thank Gerlinde Vink and Peter Nobels who contributed on the trials of methodology for micronutrient analysis in the plant samples.

\section{Compliance with ethical standards}

Conflict of interest Author S. Supriatin is a researcher in the project with a position as $\mathrm{PhD}$ candidate. Author L. Weng is a researcher in the project with a position as co-promotor and supervisor of the $\mathrm{PhD}$ candidate. Author R.N.J Comans is a leader in the project with a position as promotor of the $\mathrm{PhD}$ candidate. We declare that we have no conflict of interest. 


\section{Appendix}

Fig. 8 a Correlation between yield and Se content of wheat shoots and $\mathbf{b}$ Correlation between Se uptake and Se content of wheat shoots
Fig. 9 a Correlation between soil $\mathrm{pH}$ (pH measured in $0.01 M$ $\mathrm{CaCl}_{2}$ and hot water extractions) and $\mathrm{Se}$ to organic $\mathrm{C}$ ratio in $0.01 \mathrm{M} \mathrm{CaCl}_{2}$ and hot water extractions, respectively and $\mathbf{b}$ Correlation between soil $\mathrm{pH}$ measured in $0.01 \mathrm{M} \mathrm{CaCl}_{2}$ extraction and Se to organic $\mathrm{C}$ ratio in $0.43 \mathrm{M} \mathrm{HNO}_{3}$,

ammonium oxalate extractions and total content (Se aqua regia:total organic $\mathrm{C}$ )
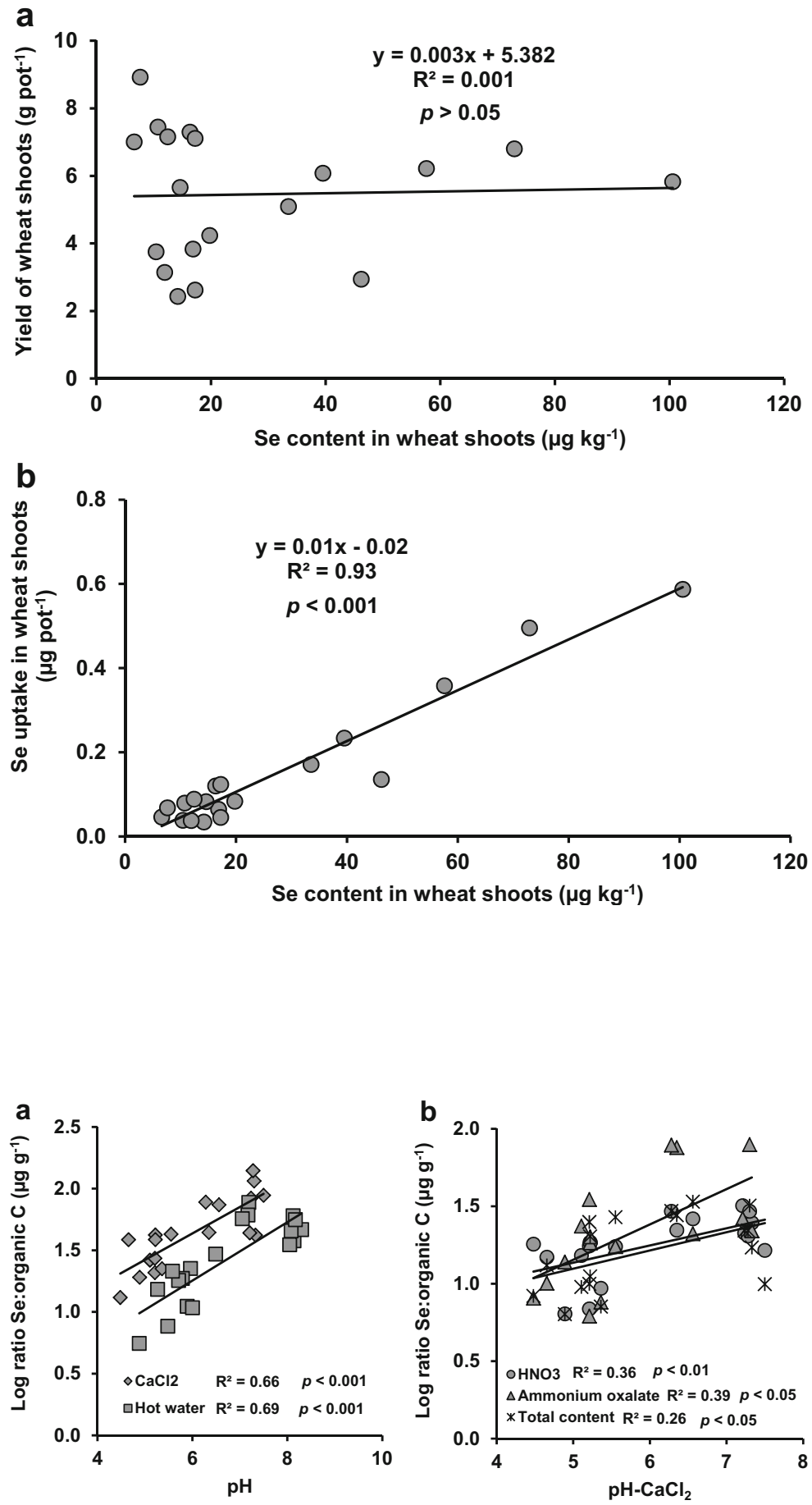
Table 6 Amount and fraction of Se extracted in $0.43 \mathrm{MHNO}_{3}$, hot water and ammonium oxalate. The data are presented as mean \pm standard deviation per soil type. Values in brackets are ranges of the Se amount and fraction in each extraction per soil type

\begin{tabular}{|c|c|c|c|c|c|c|}
\hline \multirow[t]{2}{*}{ Soil type } & \multicolumn{3}{|l|}{ Se extracted $\left(\mu \mathrm{g} \mathrm{kg}^{-1}\right)$} & \multicolumn{3}{|c|}{$\begin{array}{l}\text { Se extraction efficiency ( } \% \text { of total Se-aqua } \\
\text { regia) }\end{array}$} \\
\hline & $\mathrm{HNO}_{3}$ & hot water & ammonium oxalate & $\mathrm{HNO}_{3}$ & hot water & $\begin{array}{l}\text { ammonium } \\
\text { oxalate }\end{array}$ \\
\hline Sand $(n=5)$ & $\begin{array}{l}23.3 \pm 7.9(12.0- \\
32.0)\end{array}$ & $\begin{array}{l}17.7 \pm 2.4(13.8- \\
19.7)\end{array}$ & $80.0 \pm 37.7(38-140)$ & $\begin{array}{c}7 \pm 3^{\mathrm{a}}(3- \\
11)^{\mathrm{a}}\end{array}$ & $\begin{array}{l}5 \pm 2^{\mathrm{a}}(3- \\
7)^{\mathrm{a}}\end{array}$ & $21 \pm 3^{\mathrm{a}}(18-25)^{\mathrm{a}}$ \\
\hline $\begin{aligned} \text { Clay } & \geq 20 \%, \mathrm{pH}>6 \\
(n & =3)\end{aligned}$ & $8.3 \pm 1.2(7.0-9.0)$ & $\begin{array}{l}20.5 \pm 0.5(19.9- \\
20.9)\end{array}$ & $86.0^{\mathrm{b}}$ & $3 \pm 0.7(3-4)$ & $8 \pm 1(6-9)$ & $38^{\mathrm{b}}$ \\
\hline Other clay $(n=6)$ & $12.2 \pm 5.4(7.0-22.0)$ & $\begin{array}{l}19.8 \pm 5.2(14.1- \\
29.5)\end{array}$ & $\begin{array}{l}77.6 \pm 40.2^{\mathrm{b}}(50- \\
146)^{\mathrm{b}}\end{array}$ & $3 \pm 0.4(3-4)$ & $6 \pm 2(2-9)$ & $19 \pm 9^{\mathrm{b}}(12-34)^{\mathrm{b}}$ \\
\hline Loess $(n=1)$ & 18.0 & 25.2 & 146.0 & 2 & 3 & 20 \\
\hline Reclaimed peat $(n=4)$ & $11.8 \pm 3.9(8.0-17.0)$ & $12.2 \pm 4.7(6.4-16.9)$ & $66.5 \pm 15.8(50-80)$ & $3 \pm 1(2-4)$ & $3 \pm 1(2-4)$ & $17 \pm 4(11-19)$ \\
\hline Average $\pm \mathbf{S D}^{\mathrm{c}}$ & $14.7 \pm 7.5$ & $18.1 \pm 5.0$ & $80.4 \pm 34.7$ & $4 \pm 2$ & $\mathbf{5} \pm \mathbf{2}$ & $21 \pm 7$ \\
\hline
\end{tabular}

${ }^{a}$ One sample that has a total Se content (aqua regia) below the determination limit was excluded from the table

${ }^{\mathrm{b}}$ Soil samples that have Se concentrations below the determination limit were excluded from the table

c Standard deviation

Table 7 Selenium speciation in ammonium oxalate extraction using HPLC - ICP-MS

\begin{tabular}{|c|c|c|c|c|c|c|c|c|}
\hline \multirow[t]{2}{*}{ Soil type } & \multicolumn{2}{|c|}{$\begin{array}{l}\text { Total Se ammonium } \\
\text { oxalate }\left(\mu \mathrm{g} \mathrm{kg}^{-1}\right)\end{array}$} & \multicolumn{2}{|c|}{$\begin{array}{l}\text { Inorganic } \\
\text { selenite }^{a} / \text { total Se } \\
\text { ammonium oxalate }(\%)\end{array}$} & \multicolumn{2}{|c|}{$\begin{array}{l}\text { Organic } \mathrm{Se}^{\mathrm{b}} / \text { total } \\
\text { Se ammonium } \\
\text { oxalate }(\%)\end{array}$} & \multirow{2}{*}{$\begin{array}{l}\text { Total Se aqua } \\
\text { regia }\left(\mu \mathrm{g} \mathrm{kg}^{-1}\right) \\
\text { Average } \pm \mathrm{SD}^{\mathrm{c}}\end{array}$} & \multirow{2}{*}{$\begin{array}{l}\text { Inorganic selenite } \mathrm{a} \\
\text { total Se aqua regia } \\
(\%) \\
\text { Average } \pm \mathrm{SD}^{\mathrm{c}}\end{array}$} \\
\hline & Range & Average $\pm \mathrm{SD}^{\mathrm{c}}$ & Range & Average $\pm \mathrm{SD}^{\mathrm{c}}$ & Range & Average $\pm \mathrm{SD}^{\mathrm{c}}$ & & \\
\hline Sand $(n=5)$ & $38-140$ & $80 \pm 38$ & $0-28$ & $15 \pm 12$ & $72-100$ & $85 \pm 12$ & $437 \pm 179^{d}$ & $3 \pm 2^{\mathrm{d}}$ \\
\hline $\begin{aligned} \text { Clay } & \geq 20 \%, \mathrm{pH}>6 \\
(n & =3)\end{aligned}$ & n.d. ${ }^{\text {ef }}$ & $86^{\mathrm{e}}$ & n.d. ${ }^{\text {ef }}$ & $19^{\mathrm{e}}$ & n.d. ${ }^{\text {ef }}$ & $81^{\mathrm{e}}$ & $262 \pm 43$ & $7^{\mathrm{e}}$ \\
\hline Other clay $(n=6)$ & $50-146^{\mathrm{e}}$ & $78 \pm 40^{\mathrm{e}}$ & $10-45^{\mathrm{e}}$ & $28 \pm 13^{\mathrm{e}}$ & $55-90^{\mathrm{e}}$ & $72 \pm 13^{\mathrm{e}}$ & $392 \pm 187$ & $5 \pm 2^{\mathrm{e}}$ \\
\hline Loess $(n=1)$ & n.d. ${ }^{\mathrm{f}}$ & 146 & n.d. ${ }^{f}$ & 7 & n.d. ${ }^{f}$ & 93 & 734 & 1.4 \\
\hline Reclaimed peat $(n=4)$ & $50-80$ & $67 \pm 16$ & n.d. ${ }^{f}$ & 0 & n.d. ${ }^{\mathrm{f}}$ & 100 & $404 \pm 103$ & 0 \\
\hline Average $\pm \mathbf{S D}^{\mathrm{c}}$ & & $\mathbf{8 0} \pm 35$ & & $15 \pm 14$ & & $85 \pm 14$ & $734 \pm 168$ & $\mathbf{3} \pm \mathbf{3}$ \\
\hline
\end{tabular}

${ }^{\text {a } I n o r g a n i c ~ s e l e n i t e ~ a s ~ e x t r a c t e d ~ w i t h ~ a m m o n i u m ~ o x a l a t e ~}$

${ }^{\mathrm{b}}$ Organic Se in ammonium oxalate extraction was derived from the difference between total Se concentration and inorganic selenite in the ammonium oxalate extraction

${ }^{\mathrm{c}}$ Standard deviation

${ }^{\mathrm{d}}$ One sample that has a total Se content (aqua regia) below the determination limit was excluded from the table

${ }^{\mathrm{e}}$ In ammonium oxalate extraction, soil samples that have Se concentrations below the determination limit were excluded from the table

f $n . d$. not determined 
Table 8 Results of multiple (two to four factors) linear regressions between $\log _{10}$ (Se in wheat shoots, $\mu \mathrm{g} \mathrm{kg}^{-1}$ ) as a dependent parameter (Y) and $\log _{10}$ (soil parameters) as independent parameters $\left(\mathrm{X}_{1}, X_{2}, \ldots\right)(n=19)$, with an adjusted $\mathrm{R}^{2}>0.50$

Model Intercept Coefficients of independent parameters $\left(b_{1}, b_{2}, \ldots\right)$

\begin{tabular}{lllllll}
\hline $\begin{array}{l}\text { Soil C:N } \\
\text { ratio }\end{array}$ & $\mathrm{pH}^{-\mathrm{CaCl}_{2}{ }^{\mathrm{a}}}$ & $\begin{array}{l}\mathrm{pH}-\mathrm{hot} \\
\text { water }\end{array}$ & $\begin{array}{l}\text { Organic } \\
\text { matter } \\
(\%)\end{array}$ & $\begin{array}{l}\mathrm{DOC}-\mathrm{CaCl}_{2} \\
\left(\mathrm{mg} \mathrm{kg}^{-1}\right)\end{array}$ & $\begin{array}{l}\mathrm{DON}-\mathrm{CaCl}_{2} \\
\left(\mathrm{mg} \mathrm{kg}^{-1}\right)\end{array}$ & $\begin{array}{l}\text { DOC-hot } \\
\text { water } \\
\left(\mathrm{mg} \mathrm{kg}^{-1}\right)\end{array}$ \\
\end{tabular}

\begin{tabular}{|c|c|c|c|c|c|c|c|c|}
\hline Model 1 & 0.90 & -0.65 & 0.19 & & & & & \\
\hline Model 2 & 0.96 & -0.68 & & 0.17 & & & & \\
\hline Model 3 & 4.59 & -1.12 & & & & -1.10 & & \\
\hline Model $4^{\mathrm{b}}$ & 5.18 & -1.33 & & & & & & \\
\hline Model 5 & 0.48 & & 0.17 & & -0.33 & & & \\
\hline Model 6 & 1.53 & & 0.17 & & & -0.67 & & \\
\hline Model 7 & 0.43 & & 0.21 & & & & -0.38 & \\
\hline Model 8 & 0.07 & & 0.19 & & & & & \\
\hline Model 9 & -0.07 & & 0.18 & & & & & \\
\hline Model $10^{\mathrm{b}}$ & 0.70 & & 0.18 & & & & & \\
\hline Model $11^{\mathrm{b}}$ & 0.94 & & 0.23 & & & & & \\
\hline Model 12 & 0.53 & & & 0.15 & -0.35 & & & \\
\hline Model 13 & 0.24 & & & 0.15 & & & & -0.36 \\
\hline Model 14 & 0.10 & & & 0.16 & & & & \\
\hline Model 15 & -0.52 & & & 0.20 & & & & \\
\hline Model $16^{\mathrm{b}}$ & 0.73 & & & 0.16 & & & & \\
\hline Model $17^{\mathrm{b}}$ & 1.09 & & & 0.20 & & & & \\
\hline Model 18 & 2.10 & & & & -0.61 & & -0.42 & \\
\hline Model 19 & 1.43 & & & & -0.50 & & & \\
\hline Model 20 & 1.32 & & & & -0.51 & & & \\
\hline Model 21 & 0.95 & & & & -0.65 & & & \\
\hline Model $22^{\mathrm{b}}$ & 2.51 & & & & -0.74 & & & \\
\hline Model 23 & 3.66 & & & & & -1.09 & -0.37 & \\
\hline Model 24 & 3.12 & & & & & -1.14 & & \\
\hline Model 25 & 3.09 & & & & & -1.23 & & \\
\hline Model $26^{\mathrm{b}}$ & 3.47 & & & & & -1.01 & & \\
\hline Model 27 & 1.28 & & & & & & -0.41 & \\
\hline Model 28 & 0.54 & & & & & & & -0.86 \\
\hline Model $29^{\mathrm{b}}$ & 2.65 & & & & & & & -0.85 \\
\hline Model $30^{\mathrm{b}}$ & 1.74 & & & & & & & \\
\hline Model $31^{\mathrm{b}}$ & 3.63 & & & & & & & \\
\hline Model $32^{\mathrm{b}}$ & 3.32 & & & & & & & \\
\hline Model $33^{b}$ & 2.84 & & & & & & & \\
\hline Model 34 & 0.79 & -0.53 & 0.18 & & & & & \\
\hline Model 35 & 3.14 & -0.05 & & & & -1.22 & & \\
\hline Model 36 & 0.17 & -0.16 & 0.18 & & & & & \\
\hline Model 37 & 3.42 & -0.27 & & & & -1.11 & & \\
\hline Model 38 & 3.35 & -0.86 & 0.08 & & & -0.84 & & \\
\hline Model 39 & 0.20 & -0.20 & 0.18 & & & & & \\
\hline Model 40 & 3.81 & -0.25 & -0.04 & & & -1.24 & & \\
\hline Model 41 & 3.05 & -0.04 & 0.007 & & & -1.20 & & \\
\hline Model 42 & 2.71 & 0.26 & & & & -1.21 & & \\
\hline Model 43 & 2.99 & & 0.009 & & & -1.20 & & \\
\hline Model 44 & 3.02 & & & & & -1.18 & & \\
\hline Model 45 & 3.71 & & -0.06 & & & -1.39 & & \\
\hline Model 46 & 3.58 & & -0.04 & & & -1.27 & & \\
\hline
\end{tabular}


Table 8 (continued)

\begin{tabular}{|c|c|c|c|c|c|c|c|c|}
\hline \multirow[t]{2}{*}{ Model } & \multirow[t]{2}{*}{ Intercept } & \multicolumn{7}{|c|}{ Coefficients of independent parameters $\left(b_{1}, b_{2}, \ldots\right)$} \\
\hline & & $\begin{array}{l}\text { Soil } \mathrm{C}: \mathrm{N} \\
\text { ratio }\end{array}$ & $\mathrm{pH}-\mathrm{CaCl}_{2}{ }^{\mathrm{a}}$ & $\begin{array}{l}\text { pH-hot } \\
\text { water }^{\mathrm{a}}\end{array}$ & $\begin{array}{l}\text { Organic } \\
\text { matter } \\
(\%)\end{array}$ & $\begin{array}{l}\mathrm{DOC}-\mathrm{CaCl}_{2} \\
\left(\mathrm{mg} \mathrm{kg}^{-1}\right)\end{array}$ & $\begin{array}{l}\mathrm{DON}-\mathrm{CaCl}_{2} \\
\left(\mathrm{mg} \mathrm{kg}^{-1}\right)\end{array}$ & $\begin{array}{l}\text { DOC-hot } \\
\text { water } \\
\left(\mathrm{mg} \mathrm{kg}^{-1}\right)\end{array}$ \\
\hline Model 47 & 0.42 & & 0.16 & & & & -0.32 & \\
\hline Model 48 & 0.94 & & 0.15 & & -0.28 & & -0.36 & \\
\hline Model 49 & 0.97 & -0.38 & 0.18 & & & & -0.33 & \\
\hline Model 50 & 0.46 & & 0.19 & & & & -0.35 & 0.04 \\
\hline
\end{tabular}

Model Coefficients of independent parameters $\left(b_{1}, b_{2}, \ldots\right)$

Adjusted $\mathrm{R}^{2} \quad p$ value

\begin{tabular}{|c|c|c|c|c|}
\hline Clay (\%) & $\begin{array}{l}\mathrm{Se}-\mathrm{CaCl}_{2} \\
\left(\mu \mathrm{g} \mathrm{kg}^{-1}\right)\end{array}$ & $\begin{array}{l}\text { Se-hot } \\
\text { water } \\
\left(\mu \mathrm{gg}^{-1}\right)\end{array}$ & $\begin{array}{l}\text { Selenite } \\
\left(\mu \mathrm{g} \mathrm{kg}^{-1}\right)\end{array}$ & $\begin{array}{l}\text { Total Se } \\
\text { (aqua } \\
\text { regia) } \\
\left(\mu \mathrm{g} \mathrm{kg}^{-1}\right)\end{array}$ \\
\hline
\end{tabular}

\begin{tabular}{|c|c|c|c|c|c|c|c|}
\hline Model 1 & & & & & & 0.60 & $<0.001$ \\
\hline Model 2 & & & & & & 0.59 & $<0.001$ \\
\hline Model 3 & & & & & & 0.70 & $<0.001$ \\
\hline Model $4^{\mathrm{b}}$ & & & & & -0.92 & 0.57 & $<0.001$ \\
\hline Model 5 & & & & & & 0.60 & $<0.001$ \\
\hline Model 6 & & & & & & 0.62 & $<0.001$ \\
\hline Model 7 & & & & & & 0.68 & $<0.001$ \\
\hline Model 8 & 0.15 & & & & & 0.58 & $<0.001$ \\
\hline Model 9 & & 0.60 & & & & 0.65 & $<0.001$ \\
\hline Model $10^{\mathrm{b}}$ & & & & -0.40 & & 0.58 & $<0.01$ \\
\hline Model $11^{\mathrm{b}}$ & & & & & -0.39 & 0.64 & $<0.001$ \\
\hline Model 12 & & & & & & 0.59 & $<0.001$ \\
\hline Model 13 & & & & & & 0.55 & $<0.001$ \\
\hline Model 14 & 0.16 & & & & & 0.57 & $<0.001$ \\
\hline Model 15 & & & 0.42 & & & 0.56 & $<0.001$ \\
\hline Model $16^{\mathrm{b}}$ & & & & -0.42 & & 0.57 & $<0.01$ \\
\hline Model $17^{\mathrm{b}}$ & & & & & -0.44 & 0.62 & $<0.001$ \\
\hline Model 18 & & & & & & 0.60 & $<0.001$ \\
\hline Model 19 & 0.24 & & & & & 0.56 & $<0.001$ \\
\hline Model 20 & & 0.68 & & & & 0.56 & $<0.001$ \\
\hline Model 21 & & & 0.63 & & & 0.51 & $<0.01$ \\
\hline Model $22^{\mathrm{b}}$ & & & & & -0.28 & 0.52 & $<0.01$ \\
\hline Model 23 & & & & & & 0.58 & $<0.001$ \\
\hline Model 24 & 0.32 & & & & & 0.78 & $<0.001$ \\
\hline Model 25 & & 1.01 & & & & 0.85 & $<0.001$ \\
\hline Model $26^{\mathrm{b}}$ & & & & -0.22 & & 0.56 & $<0.01$ \\
\hline Model 27 & & 0.89 & & & & 0.54 & $<0.001$ \\
\hline Model 28 & & & 0.49 & & & 0.51 & $<0.01$ \\
\hline Model $29^{\mathrm{b}}$ & & & & & -0.58 & 0.58 & $<0.001$ \\
\hline Model $30^{\mathrm{b}}$ & 0.31 & & & -0.62 & & 0.51 & $<0.01$ \\
\hline Model $31^{\mathrm{b}}$ & 0.38 & & & & -1.02 & 0.68 & $<0.001$ \\
\hline Model $32^{\mathrm{b}}$ & & 1.08 & & & -0.98 & 0.66 & $<0.001$ \\
\hline Model $33^{b}$ & & & 1.23 & & -1.19 & 0.51 & $<0.01$ \\
\hline
\end{tabular}


Table 8 (continued)

\begin{tabular}{|c|c|c|c|c|c|c|c|}
\hline \multirow[t]{2}{*}{ Model } & \multicolumn{5}{|c|}{ Coefficients of independent parameters $\left(b_{1}, b_{2}, \ldots\right)$} & \multirow[t]{2}{*}{ Adjusted $\mathrm{R}^{2}$} & \multirow[t]{2}{*}{$p$ value } \\
\hline & Clay (\%) & $\begin{array}{l}\mathrm{Se}-\mathrm{CaCl}_{2} \\
\left(\mu \mathrm{g} \mathrm{kg}^{-1}\right)\end{array}$ & $\begin{array}{l}\text { Se-hot } \\
\text { water } \\
\left(\mu \mathrm{kg}^{-1}\right)\end{array}$ & $\begin{array}{l}\text { Selenite } \\
\left(\mu \mathrm{g} \mathrm{kg}^{-1}\right)\end{array}$ & $\begin{array}{l}\text { Total Se } \\
\text { (aqua } \\
\text { regia) } \\
\left(\mu \mathrm{kg}^{-1}\right)\end{array}$ & & \\
\hline Model 34 & 0.05 & & & & & 0.58 & $<0.01$ \\
\hline Model 35 & & 0.98 & & & & 0.84 & $<0.001$ \\
\hline Model 36 & & 0.53 & & & & 0.63 & $<0.001$ \\
\hline Model 37 & 0.27 & & & & & 0.77 & $<0.001$ \\
\hline Model 38 & & & & & & 0.70 & $<0.001$ \\
\hline Model 39 & -0.03 & 0.55 & & & & 0.60 & $<0.01$ \\
\hline Model 40 & 0.32 & & & & & 0.76 & $<0.001$ \\
\hline Model 41 & & 0.97 & & & & 0.83 & $<0.001$ \\
\hline Model 42 & 0.16 & 0.81 & & & & 0.86 & $<0.001$ \\
\hline Model 43 & & 0.99 & & & & 0.84 & $<0.001$ \\
\hline Model 44 & 0.13 & 0.74 & & & & 0.87 & $<0.001$ \\
\hline Model 45 & 0.19 & 0.76 & & & & 0.87 & $<0.001$ \\
\hline Model 46 & 0.37 & & & & & 0.77 & $<0.001$ \\
\hline Model 47 & & 0.48 & & & & 0.73 & $<0.001$ \\
\hline Model 48 & & & & & & 0.70 & $<0.001$ \\
\hline Model 49 & & & & & & 0.68 & $<0.001$ \\
\hline Model 50 & & & & & & 0.66 & $<0.001$ \\
\hline
\end{tabular}

${ }^{\mathrm{a}} \mathrm{pH}$ is not converted into $\log _{10}$

${ }^{\mathrm{b}}$ The samples that have Se concentrations below the determination limit were not included in the regression analysis

Open Access This article is distributed under the terms of the Creative Commons Attribution 4.0 International License (http://creativecommons.org/licenses/by/4.0/), which permits unrestricted use, distribution, and reproduction in any medium, provided you give appropriate credit to the original author(s) and the source, provide a link to the Creative Commons license, and indicate if changes were made.

\section{References}

Abrams MM, Burau RG (1989) Fractionation of selenium and detection of selenomethionine in a soil extract. Commun Soil Sci Plant Anal 20:221-237

Abrams MM, Burau RG, Zasoski RJ (1990a) Organic selenium distribution in selected California soils. Soil Sci Soc Am J 54: 979-982

Abrams MM, Shennan C, Zasoski RJ, Burau RG (1990b) Selenomethionine uptake by wheat seedlings. Agron J 82: $1127-1130$
Adams ML, Lombi E, Zhao FJ, McGrath SP (2002) Evidence of low selenium concentrations in UK bread-making wheat grain. J Sci Food Agric 82:1160-1165

Curtin D, Campbell CA, Jalil A (1998) Effects of acidity on mineralization: $\mathrm{pH}$-dependence of organic matter mineralization in weakly acidic soils. Soil Biol Biochem 30:57-64

De Temmerman L, Waegeneers N, Thiry C, Laing GD, Tack F, Ruttens A (2014) Selenium content of Belgian cultivated soils and its uptake by field crops and vegetables. Sci Total Environ 468-469:77-82

Eich-Greatorex S, Sogn TA, Øgaard AF, Aasen I (2007) Plant availability of inorganic and organic selenium fertiliser as influenced by soil organic matter content and $\mathrm{pH}$. Nutr Cycl Agroecosyst 79:221-231

Gardiner MR, Gorman RC (1963) Further observations on plant selenium levels in Western Australia. Aust J Exp Agric Anim Husb 3:284-289

Ghani A, Dexter M, Perrott KW (2003) Hot-water extractable carbon in soils: a sensitive measurement for determining impacts of fertilisation, grazing and cultivation. Soil Biol Biochem 35:1231-1243

Gissel-Nielsen G (1971) Influence of pH and texture of the soil on plant uptake of added selenium. J Agric Food Chem 19:1165-1167 
Gissel-Nielsen G (1975) Selenium concentration in Danish forage crops. Acta Agric Scand 25:216-220

Gupta UC, Gupta SC (2000) Selenium in soils and crops, its deficiencies in livestock and humans: implication for management. Commun Soil Sci Plant Anal 31: 1791-1807

Gustafsson JP, Johnsson L (1994) The association between selenium and humic substances in forested ecosystems - Laboratory evidence. Appl Organomet Chem 8:141-147

Hartfiel W, Bahners N (1988) Selenium deficiency in the Federal Republic of Germany. Biol Trace Elem Res 15:1-11

Hartikainen H (2005) Biogeochemistry of selenium and its impact on food chain quality and human health. J Trace Elem Med Biol 18:309-318

Hawkesford MJ, Zhao FJ (2007) Strategies for increasing the selenium content of wheat. J Cereal Sci 46:282-292

Homann PS, Kapchinske JS, Boyce A (2007) Relations of mineral-soil $\mathrm{C}$ and $\mathrm{N}$ to climate and texture: regional differences within the conterminous USA. Biogeochemistry 85 : 303-316

Hopper JL, Parker DR (1999) Plant availability of selenite and selenate as influenced by the competing ions phosphate and sulfate. Plant Soil 210:199-207

Houba VJG, Temminghoff EJM, Gaikhorst GA, Van Vark W (2000) Soil analysis procedures using $0.01 \mathrm{M}$ calcium chloride as extraction reagent. Commun Soil Sci Plant Anal 31: 1299-1396

Hurd-Karrer AM (1938) Relation of sulphate to selenium absorption by plants. Am J Bot 25:666-675

Jiang Y, Zeng ZH, Bu Y, Ren CZ, Li JZ, Han JJ, Tao C, Zhang K, Wang XX, Lu GX, Li YJ, Hu YG (2015) Effects of selenium fertilizer on grain yield, Se uptake and distribution in common buckwheat (Fagopyrum esculentum Moench). Plant Soil Environ 61:371-377

Johnsson L (1991) Selenium uptake by plants as a function of soil type, organic matter content and pH. Plant Soil 133:57-64

Johnsson L (1992) Selenium in Swedish soils. Factors influencing soil content and plant uptake. Department of Soil Sciences. Swedish University of Agricultural Sciences, Uppsala

Jones DL, Kielland K (2002) Soil amino acid turnover dominates the nitrogen flux in permafrost-dominated taiga forest soils. Soil Biol Biochem 34:209-219

Kalbitz K, Solinger S, Park J-H, Michalzik B, Matzner E (2000) Controls on the dynamics of dissolved organic matter in soils: a review. Soil Sci 165:277-304

Kang Y, Yamada H, Kyuma K, Hattori T, Kigasawa S (1991) Selenium in soil humic acid. Soil Sci Plant Nutr 37:241-248

Keskinen R, Ekhlom P, Yli-Halla M, Hartikainen H (2009) Efficiency of different methods in extracting selenium from agricultural soils of Finland. Geoderma 153:87-93

Kikkert J, Berkelaar E (2013) Plant uptake and translocation of inorganic and organic forms of selenium. Arch Environ Contam Toxicol 65:458-465

Li H, McGrath SP, Zhao F (2008) Selenium uptake, translocation and speciation in wheat supplied with selenate or selenite. New Phytol 178:92-102

McKeague JA, Day JH (1966) Dithionite and oxalate extractable $\mathrm{Fe}$ and $\mathrm{Al}$ as aids in differentiating various classes of soils. Can J Soil Sci 46:13-22
Mehdawi AFE, Lindblom SD, Cappa JJ, Fakra SC, Pilon-Smits EAH (2015) Do selenium hyperaccumulators affect selenium speciation in neighboring plants and soil? An X-ray microprobe analysis. Int J Phytoremediation 17:753-765

Post WM, Pastor J, Zinke PJ, Stangenberger AG (1985) Global patterns of soil nitrogen storage. Nature 317:613-616

Roca-Perez L, Gil C, Cervera ML, Gonzálvez A, Ramos-Miras J, Pons V, Bech J, Boluda R (2010) Selenium and heavy metals content in some Mediterranean soils. J Geochem Explor 107: $110-116$

Stroud JL, Broadley MR, Foot I, Fairweather-Tait SJ, Hart DJ, Hurst R, Knott P, Mowat H, Norman K, Scott P, Tucker M, White PJ, McGrath SP, Zhao FJ (2010) Soil factors affecting selenium concentration in wheat grain and the fate and speciation of Se fertilisers applied to soil. Plant Soil 332:19-30

Stroud JL, McGrath SP, Zhao F (2012) Selenium speciation in soil extracts using LC-ICP-MS. Int J Environ Anal Chem 92: 222-236

Supriatin S, Terrones CA, Bussink W, Weng L (2015a) Drying effects on selenium and copper in $0.01 \mathrm{M}$ calcium chloride soil extractions. Geoderma 255-256:104-114

Supriatin S, Weng L, Comans RNJ (2015b) Selenium speciation and extractability in Dutch agricultural soils. Sci Total Environ 532:368-382

Száková J, Tremlová J, Pegová K, Najmanová J, Tlustoš P (2015) Soil-to-plant transfer of native selenium for wild vegetation cover at selected locations of the Czech Republic. Environ Monit Asses 187:358

Tolu J, Thiry Y, Bueno M, Jolivet C, Potin-Gautier M, Hécho IL (2014) Distribution and speciation of ambient selenium in contrasted soils, from mineral to organic rich. Sci Total Environ 479-480:93-101

Wang D, Sippola J (1990) Selenium in soil extracts and plants determined by flourometry. Ann Agric Fenniae 29:151-156

Weng L, Vega FA, Supriatin S, Bussink W, Van Riemsdijk WH (2011) Speciation of Se and DOC in soil solution and their relation to Se bioavailability. Environ Sci Technol 45:262267

Williams MC, Mayland HF (1992) Selenium absorption by twogrooved milkvetch and western wheatgrass from selenomethionine, selenocystine, and selenite. J Range Manag 45:374-378

Yamada H, Hattori T (1989) Forms of soluble selenium in soil. Soil Sci Plant Nutr 35:553-563

Yanai J, Mizuhara S, Yamada H (2015) Soluble selenium content of agricultural soils in Japan and its determining factors with reference to soil type, land use and region. Soil Sci Plant Nutr 61:312-318

Yläranta T (1983) Effect of added selenite and selenate on the selenium content of Italian rye grass (Lolium multiflorum) in different soils. Ann Agric Fenniae 22:139-151

Zayed A, Lytle CM, Terry N (1998) Accumulation and volatilization of different chemical species of selenium by plants. Planta 206:284-292

Zech W, Senesi N, Guggenberger G, Kaiser K, Lehmann J, Miano TM, Miltner A, Schroth G (1997) Factors controlling humification and mineralization of soil organic matter in the tropics. Geoderma 79:117-161

Zhao C, Ren J, Xue C, Lin E (2005) Study on the relationship between soil selenium and plant selenium uptake. Plant Soil 277:197-206 